\title{
Article
}

\section{Loneliness as a predictor of suicidal ideation and behaviour: a systematic review and meta-analysis of prospective studies}

McClelland, Heather, Evans, Jonathan J., Nowland, Rebecca, Ferguson, Eamonn and O'Connor, Rory C.

Available at http://clok.uclan.ac.uk/33299/

McClelland, Heather, Evans, Jonathan J., Nowland, Rebecca ORCID: 00000003-4326-2425, Ferguson, Eamonn and O'Connor, Rory C. (2020) Loneliness as a predictor of suicidal ideation and behaviour: a systematic review and meta-analysis of prospective studies. Journal of Affective Disorders, 274 . pp. 880-896. ISSN 0165-0327

It is advisable to refer to the publisher's version if you intend to cite from the work. http://dx.doi.org/10.1016/j.jad.2020.05.004

For more information about UCLan's research in this area go to http://www.uclan.ac.uk/researchgroups/ and search for <name of research Group>.

For information about Research generally at UCLan please go to http://www.uclan.ac.uk/research/

All outputs in CLoK are protected by Intellectual Property Rights law, including Copyright law. Copyright, IPR and Moral Rights for the works on this site are retained by the individual authors and/or other copyright owners. Terms and conditions for use of this material are defined in the policies page. 


\section{Loneliness as a predictor of suicidal ideation and behaviour: a systematic review and meta-analysis of prospective studies}

Heather McClelland ${ }^{1}$, Suicidal Behaviour Research Laboratory, Institute of Health and Wellbeing, University of Glasgow

Jonathan J. Evans, Institute of Health and Wellbeing, University of Glasgow

Rebecca Nowland, School of Nursing, University of Central Lancashire

Eamonn Ferguson, School of Psychology, University of Nottingham

Rory C. O'Connor, Suicidal Behaviour Research Laboratory, Institute of Health and Wellbeing, University of Glasgow

\section{Author Accepted Manuscript}

This is the author accepted manuscript. It is advisable to refer to the publisher's version of the paper if you intend to cite from the work.

\footnotetext{
${ }^{1}$ Corresponding author Address: Suicidal Behaviour Research Laboratory, Institute of Health and Wellbeing, University of Glasgow, Admin Building, Gartnavel Royal Hospital, 1055 Great Western Road, Glasgow G12 OHX. Email: heather.mcclelland@glasgow.ac.uk
} 


\section{Abstract}

Background: Suicide and suicidal behaviour are global health concerns with complex aetiologies.

Given the recent research and policy focus on loneliness, this systematic review aimed to determine the extent to which loneliness predicts suicidal ideation and/or behaviour (SIB) over time.

Methods: A keyword search of five major databases (CINHAL, Medline, PsychArticles, PsychInfo and Web of Knowledge) was conducted. Papers for inclusion were limited to those using a prospective longitudinal design, written in English and which measured loneliness at baseline and SIB at a later time-point.

Results: After duplicates were removed, 947 original potential papers were identified, with 22 studies meeting the review criteria. Meta-analysis revealed loneliness was a significant predictor of both suicidal ideation and behaviour and there was evidence that depression acted as a mediator. Furthermore, studies which consisted of predominantly female participants were more likely to report a significant relationship, as were studies where participants were aged $16-20$ or $>55$ years at baseline.

Limitations: There was considerable variability in measures, samples and methodologies used across the studies. Middle-aged adults were under-represented, as were individuals from minority ethnic backgrounds. All studies were conducted in countries where self-reliance and independence (i.e. individualism) are the cultural norm.

Conclusions: Loneliness predicts later SIB in select populations. However, due to the heterogeneity of the studies further research is needed to draw more robust conclusions. Suicide death also needs to be included as an outcome measure. A focus on more collectivist countries is also required. Keywords: Loneliness; Suicide; Self-harm; Self-injury; Depression; Review Abbreviations: SIB, Suicidal ideation and behaviour. 
1. Introduction

Suicide is a global health concern with over 800,000 deaths by suicide worldwide every year (World Health Organization, 2017). In some countries one in nine young adults report making a suicide attempt (Wetherall et al., 2018). Progress in predicting suicidal behaviour has not improved markedly in the last 50 years (Franklin et al., 2017) and therefore identifying more specific risk factors for suicidal behaviour remains an urgent research priority.

There are many theories which offer explanations for suicidal behaviour. One such approach is the Integrated Motivational-Volitional Model of suicidal behaviour (IMV; O'Connor and Kirtley, 2011, 2018) which allows for the exploration of biological, psychological and social factors contributing to self-injurious acts. Psychological factors could be considered more enmeshed when compared to biological or social factors. Relative to psychiatric illness, psychological factors are comparatively under-researched. For the purposes of this review we focused on the psychological factor of loneliness in relation to self-injurious behaviour.

Loneliness is defined as 'when a person's network of social relations is deficient in some important way, either quantitively or qualitatively' (Perlman and Peplau, 1981, p. 31). The distinction between social isolation and loneliness is important to highlight. Social isolation is outwardly visible to an onlooker; inferred by the lack of social proximity and engagement with others, though the individual themselves may not feel alone. By contrast, loneliness is a subjective psychological state identified through introspection and thereby incorporates those who may feel lonely within a crowd (Bondevik and Skogstad, 1998).

Loneliness has gained increasing attention from national governments and public health organisations (UK Government, 2018; Loneliness Taskforce, 2018), with the recognition that worldwide, approximately $11-17 \%$ of the general population experience loneliness at some time in their lives (Beutel et al., 2017; British Red Cross, 2016; Victor and Yang, 2012). Loneliness has consistently been found to be associated with both suicidal ideation and behaviour in research studies (Hedley et al., 2018; Stickley and Koyanagi, 2016; Stravynski and Boyer, 2001; Teo et al., 2018) as well as in more general systematic reviews (Calati et al., 2019; Mushtaq et al., 2014). Furthermore, some studies suggest that loneliness is more closely related to suicide risk than perceived social support (Chang et al., 2017).

Cross-sectional research indicates that the frequency of loneliness is age-dependent (Batigun, 2005); being most prevalent in those $<30$ and $>80$ years of age (Yang and Victor, 2011); peaking in adolescence and old age (Qualter et al., 2015). These age ranges coincide with increased prevalence of suicidal behaviour (though not suicide death) in younger and older adults compared to other age groups (Nock and Prinstein, 2005; Turecki and Brent, 2016). This therefore suggests that demographic factors may influence the detection of loneliness predicting later suicidal ideation and/ 
or behaviour (SIB). However, the nature of the relationship between gender, loneliness and SIB is less clear. Although men are three times more likely to die by suicide than women (Office for National Statistics, 2019), women are more likely to experience suicidal ideation or engage in selfharm (O'Connor et al., 2018). In comparison, gender differences in loneliness have been less consistent. Some studies have found loneliness to be more prevalent in men while others have reported the reverse (De Jong Gierveld and Van Tilburg, 2010; Stokes and Levin, 1986), with a recent meta-analysis finding no gender differences in loneliness overall (Maes et al., 2019). Collectively, the evidence points to no gender difference in the association between loneliness and SIB crosssectionally (Beutel et al., 2017). These findings therefore suggest that prospectively, age may be the only demographic factor to moderate the loneliness-SIB relationship. However, given that the concept of loneliness is likely to be culturally influenced, we also aimed to investigate whether the latter relationship is affected by geographical location.

To date, prospective studies investigating the relationship between loneliness and SIB are scarce; reviews have typically focused on loneliness as a risk factor for mental health difficulties (e.g. affective disorder), specifically excluding SIB as outcome measures (Holt-Lunstad et al., 2015). These prospective reviews have found loneliness to be a stronger predictor of later depression, when compared to anxiety or substance abuse as outcome variables (Beutel et al., 2017; Van Orden et al., 2010; Vanhalst et al., 2012; Wang et al., 2018). Furthermore, as loneliness has been found to have a reciprocal relationship with depression (Cacioppo et al., 2006; Qualter, 2010), and depression is associated with SIB (Hawton et al., 2013), it could be argued that depression may mediate a prospective loneliness-SIB relationship. However, to date no review has systematically explored the role of depression in the loneliness-SIB relationship over time, and therefore we investigated its mediating role in the present review.

To robustly explore whether loneliness is a prospective risk factor of SIB, a broad definition of suicidal behaviour was used to include self-harm, with the latter defined by the National Institute for Health and Care Excellence Guidelines (NICE, 2011) as "self-injury or self-poisoning irrespective of the apparent purpose of the act". As a result, we included any studies of non-suicidal self-injury (NSSI), suicide attempts and suicide. In addition to acts of suicidal behaviour, given that approximately $12 \%$ of individuals who experience suicidal ideation or NSSI will attempt suicide within 5 years (Mars et al., 2019), we also investigated the relationship between loneliness and suicidal ideation or thoughts of self-harm.

\subsection{Current aims}

This review had the following three aims:

i) to explore whether loneliness was a significant predictor of later SIB; 
ii) to identify if the loneliness-SIB relationship varied as a function of socio-demographics (specifically age, gender) and/ or geographic location;

iii) to determine whether the loneliness-SIB relationship is mediated by depression.

2. Methods

\subsection{Research Strategy}

Five major psychological and medical databases (CINHAL, MedLine, PsychArticles, PsychInfo and Web of Knowledge) were searched up to 18th of December 2019 using the following search terms; (i) lonel* OR "perceived social isolation" OR "perceived social exclusion" AND (ii) suicid* OR "selfinjurious" or "self-injury" OR "self injurious" OR "self injury" OR "self-harm" OR "self harm". Data collection had finished before being registered with Prospero and therefore could not be listed on the website. PRISMA Guidelines (Moher et al., 2015) were followed (see Figure 1) where titles and abstracts were screened by the first author and an inter-rater check of $95 \%$ accuracy of 40 papers was conducted by a researcher external to the research team to ensure appropriate selection/exclusion of studies.

\subsection{Inclusion and exclusion criteria}

The inclusion criteria required studies to be (i) an empirical paper, (ii) written in English, (iii) reporting a prospective design (i.e. where loneliness was measured as a predictor of later SIB at a future time point) and (iv) loneliness and SIB assessments were both measured directly. Studies reporting suicidal ideation and all forms of suicidal behaviours (including suicide death, non-suicidal self-harm and suicide attempt) were included. Papers were excluded if i) they were a review paper, ii) they explored assisted suicide, or iii) loneliness was inferred by using an indirect measure (e.g. living status). Any uncertainty regarding the inclusion or exclusion criteria was discussed between the study authors until agreement was reached.

\section{Insert Figure 1 here}

\subsection{Data Extraction}

Study sample demographics, key measures, findings, analyses, confounding variables and author interpretations were extracted by the first author and collated on a data extraction sheet.

$47 \%(n=9)$ of included papers were checked by an external researcher (a psychology graduate) for inter-rater reliability with $100 \%$ concordance after discussion.

\subsection{Quality assessment}

A quality assessment tool (see table 1) was designed specifically for this review based on the Quality Assessment Tool for Systematic Observational studies (QATSO; Wong et al., 2008). Quality assessments were based on the aims of this review and therefore any extensive analysis of measures 
used for other variables was not considered when evaluating each study against the quality assessment criteria. Quality assessments were completed by the first author and $20 \%$ of the papers were checked by another researcher external to the team for inter-rater reliability. Disagreements between the researchers were resolved via discussion with $100 \%$ post-discussion concordance. Quality assessment scores were calculated with higher totals reflecting higher quality studies (max score= 8).

\subsection{Statistical analyses}

Comprehensive Meta-Analysis (version 3, Borenstein et al., 2013) was used to conduct all metaanalyses, weighted by sample size. Moderation analysis was used to explore whether findings varied as a function of gender, age and quality assessment score. Due to the small number of studies, it was not possible to examine moderating effects for studies of suicidal ideation and behaviour outcomes separately. In each moderation analysis, averages were calculated for studies where multiple effect sizes were reported (e.g. across multiple timepoints or suicidal ideation and behaviour). In all cases where gender ratio was reported, this was done so using a binary scale. Subgroup analyses of gender were dichotomised based on gender prevalence within the sample (i.e., sample demographics were $\geq 50 \%$ female vs $<50 \%$ female) as well as investigated continuously (i.e., $\%$ female in the sample). Moderation analysis of age was based on all studies where the mean age of the participant sample was reported and this was treated as a continuous variable. Analysis of depression as a mediator between loneliness and SIB was conducted using calculated r-values.

\section{Insert Table 1 here}

\section{Results}

As illustrated in Figure 1, a total of 947 original studies were initially identified by database searches for potential inclusion in the systematic review, of which 20 met the review criteria. One further article was identified through a search of references of included studies, resulting in a total of 21 papers selected for the review. This included one manuscript that published two studies within the same paper (Kleiman et al., 2017), one study that reported only some of their outcome measures (Bennardi et al., 2019), three papers that measured loneliness at two timepoints (Gallagher et al, 2014; Hom et al., 2019; Schinka et al., 2013) and a final paper that, despite being an editorial (Pietrzak et al., 2017), it was agreed between the review authors that this study should be included as it was consistent with the inclusion and exclusion criteria of this review. See Appendix 1 for additional information regarding these studies and how they are referred to within this review. In all, 22 studies from 21 papers are discussed in this systematic review, with 28 results regarding 
loneliness as a predictor of later SIB. Summaries of each study's sample demographics, measures used, findings and quality assessment score are displayed in Table 2.

\section{Insert Table 2 here}

Where relevant data were not available in the papers, authors of the studies included in this review were contacted for additional information for inclusion in the meta-analysis. In total, 17 studies (23 effect sizes) were included in the meta-analysis (see Appendix 2 for details of excluded studies). Effect sizes used were either reported by study authors or calculated by the authors of this review from information available in the paper. In order to effectively synthesise the findings from the papers included in this review, factors that influence the loneliness-SIB relationship were also critically examined in tandem with the aims outlined in the introduction. To investigate the extent to which loneliness predicts SIB, the results presented here are grouped by outcome variable (suicidal ideation vs. all suicidal behaviour including suicide death, suicide attempt and non-suicidal selfharm). The results of this review are separated by approach, with narrative summaries discussed in section 3.1 and meta-analytical findings discussed in 3.2.

\subsection{Narrative Summary of Study Findings}

This section discusses all 22 studies included in the review. The results are presented as follows:

i. Identification of a loneliness-SIB relationship

ii. Methodological quality

iii. Evidence of a loneliness-SIB relationship in adjusted and unadjusted univariate analyses;

iv. Moderating effects of socio-demographic characteristics (age, gender, ethnicity) or geographical location on to the loneliness-SIB relationship;

v. The role of depression as a mediator of the loneliness-SIB relationship;

vi. Other confounding variables (e.g. psychometric measures used, follow-up duration, study sample size, recruiting sites) affecting loneliness-SIB relationship

\subsubsection{Identification of a loneliness-SIB relationship}

17 studies (20 analyses) explored suicidal ideation as an outcome, while seven studies (eight results) measured suicidal behaviour, this includes two studies which measured both suicidal ideation and behaviour at two different timepoints (see Table 2). Of the 20 analyses that explored suicidal ideation 12 results indicated that loneliness was a significant predictor variable. Additionally, Stein et al. (2017) reported an indirect pathway from post-traumatic stress syndrome (PTSS) to loneliness at the same timepoint predicting later suicidal ideation. Gallagher et al. (2014; T2-T3) reported a significant association while Gallagher et al. (2014; T1-T3) did not. Three (Junker et al., 2017; Nickel, 2006; Wichstrøm, 2009) of the seven studies (8 analyses) which explored any form of suicidal behaviour found loneliness to be a significant predictor. Studies which 
reported a significant association were all those which explored self-harm as the outcome. Of the six studies to measure suicide attempt, the only study to report a significant association with loneliness and suicide attempt was Wichstrøm (2009), however for this study suicide attempt and self-harm was measured as a single outcome variable.

\subsubsection{Methodological quality}

Individual quality assessment scores are reported in Table 2 . The maximum score obtainable was nine. The mean score across the 22 studies was $5.18 \pm 1.8$ (range: 2 to 8 ). The lowest scoring domain was study design, where under a third of studies reported using representative samples.

\subsubsection{Unadjusted Univariate Analysis}

Across the 22 studies in this review, 26 unadjusted and nine adjusted effect sizes were reported, including seven studies that reported both adjusted and unadjusted results. Of the 26 unadjusted effect sizes ( $n=20$ studies) identified within the systematic review, half reached the generally accepted level of statistical significance $(p<0.05)$. In those studies where a significant loneliness-SIB association was found, they tended to be European-based studies, to have larger than average sample size, and to include participants that were predominantly female. Six studies (seven analyses) explored the unadjusted relationship between loneliness and suicidal behaviour with only two of these studies finding a significant loneliness- suicidal behaviour association; these studies were also the only two studies to include self-harm without suicidal intent as an outcome variable (Nickel et al. 2006; Wichstrøm, 2009). However, it should be noted that Wichstrøm's (2009) measure of suicidal behaviour included both self-harm and suicide attempt. By comparison, 11 of the 19 studies identified a significant unadjusted effect size between loneliness and suicidal ideation. This included all European studies which measured suicidal ideation, further trends were not identified.

\subsubsection{Adjusted Univariate Analyses}

Nine studies reported adjusted effect sizes, descriptions of the controlled variables are summarised in Appendix 3. Four of these studies reported that the loneliness-SIB relationship remained significant after controlling for various demographic factors (Ayalon and Shiovitz-Ezra, 2011; Bennardi et al., 2019; Junker et al., 2017; Stein et al., 2017). There was no discernible pattern of associations between control variables and the loneliness SIB relationship.

\subsubsection{Age}

Across all 22 studies there was evidence that the association between loneliness and SIB was age dependent. Participants ranged in age (at baseline) from 9 to 102 years old across the included studies (see Table 2). Studies exploring either younger (16 to 20 years, n=7; Groholt et al., 2006; Hom et al., 2009; Joiner and Rudd, 1996; Junker et al., 2017; Lasgaard et al., 2011; McGraw et a., 2008; Wichstrøm, 2009) or older adults ( $\geq 58$ years, $n=5$; Ayalon and Shiovitz-Ezra, 2011; Bonner and 
Rich, 1988, Joling et al., 2018; Pietrzak et al., 2017; Stolz et al., 2016) were more likely to identify loneliness as a significant predictor of SIB than studies with an average participant age either less than 14 years (Gallagher et al., 2014 T1-T2; Salzinger et al., 2007; Schinka et al., 2013 T1-T3 and T2T3) or between 23 to 54 years old on average ( $n=3$; Kleiman et al., 2017, Study 2; Stein et al., 2017; Trakhtenbrot et al., 2016). Only two of the studies in this review directly explored age differences as a study aim and both used suicidal ideation as the outcome variable. Ayalon and Shiovitz-Ezra (2011) found that loneliness did not predict later suicidal ideation in those over 75 years of age but did in those aged 55-65 and 66-75 years. Bennardi et al. (2019) found that loneliness only predicted suicidal ideation in the participant group aged $>60$ years old in comparison to those aged under 60 years of age.

\subsubsection{Gender}

The collective distribution of men and women in the selected studies was slightly higher than that of the world population (The World Bank, 2019); mean (\% female) $57.6 \pm$ sd. 28.8. Only two studies focused on a single gender (Stein et al., 2017, male-only; Nickel et al., 2006 female-only). Ten (Ayalon and Shiovitz-Ezra, 2011; Bonner and Rich, 1988; Gallagher et al., 2014 T1-T3; Hom et al., 2019; Joling et al., 2018; Lasgaard et al., 2011; McGraw, 2008; Nickel et al., 2006; Stolz et al., 2016; Wichstrøm, 2009) of the 15 studies (20 analyses) that recruited predominantly female participants ( $>50 \%$ female participants) found loneliness to be a significant predictor of later SIB compared to three of the seven studies (eight analyses) that contained predominantly male participants.

\subsubsection{Ethnicity}

Nine studies reported the ethnicity of the study sample; eight studies included primarily white participants (Fulginiti et al, 2018; Gallagher et al. 2014; Hom et al. 2019; Joiner and Rudd, 1996; Kleiman et al., 2017 Study 1; Kleiman et al., 2017, Study 2; Pietrzak et al., 2017; Schinka et al., 2013) while Salzinger (2007) recruited predominantly Hispanic participants (54\%). Due to the variability of outcome measures and other participant demographics, no inferences could be made regarding the role of ethnicity in relation to the relationship between loneliness and SIB.

\subsubsection{Geography}

All studies were conducted in high income, Western countries, most commonly either in the USA (n=9; Bonner and Rich, 1988; Fulginiti et al., 2018; Gallagher et al., 2014; Hom et al. 2019; Joiner and Rudd, 1996; Kleiman et al., 2017, Study 2; Pietrzak et al., 2017; Salzinger, 2007; Schinka et al., 2013) or Europe (n=9; Ayalon and Shiovitz-Ezra, 2011; Bennardi et al., 2019; Groholt et al., 2006; Joling et al., 2018; Junker et al., 2017; Lasgaard et al., 2011; Nickel et al., 2006; Stolz et al., 2016; Wichstrøm, 2009). Eight European studies identified a significant univariate relationship between loneliness and later suicidal ideation (Ayalon and Shiovitz-Ezra, 2011; Bennardi et al., 2019; Joling et al., 2018; 
Lasgaard et al., 2011; Stolz et al., 2016) and behaviour (Junker et al., 2017; Nickel, 2006; Wichstrøm, 2009). Groholt et al. (2006) did not identify a significant loneliness-SIB association however this study also had the smallest sample size. USA-based results were more equivocal, with five of the nine studies reporting a significant loneliness-SIB association including Gallagher et al. (2014) who reported a significant association in one analysis (between Time 2 and Time 3 ) but not in another (between Time 1 and Time 3).

Of the remaining studies, those conducted in Israel (Stein et al., 2017; Trakhtenbrot et al., 2016) or worldwide (Kleiman et al., 2017 Study 1) found that loneliness was not a significant predictor of SIB, while a significant association between loneliness and later suicidal ideation was identified in the Australian study (McGraw et al., 2008).

\subsubsection{Other factors associated with the loneliness-SIB relationship}

Other factors which were associated with the identification and detection of a loneliness-SIB relationship are summarised below. These include the measures employed in each study, as well as sample size, generalisability of the study sample to the target population, where participants were recruited from and duration of the follow-up.

\subsubsection{Suicidal Ideation Measures}

As noted in section 3.1.1, 17 studies recorded suicidal ideation (see table 2). Seven studies employed a single-item measure taken from a larger psychometric assessment (Ayalon and Shiovitz-Ezra, 2011; Fulginiti et al., 2018; Joling et al., 2018; 2008; Pietrzak et al., 2017; Schinka et al., 2013; Stein et al., 2017; Stolz et al., 2016) of which four identified loneliness as a significant predictor of later suicidal ideation. Studies which used a subscale from a wider measure (Bennardi et al., 2019; Hom et al., 2019; Joiner and Rudd, 1996; Lasgaard et al., 2011) consistently found an unadjusted univariate association between loneliness and SIB. Salzinger et al. (2007) measured suicidal ideation based on four items from a larger measure and found no significant association. Two studies (three results) using a bespoke questionnaire (Bonner and Rich, 1988; Gallagher et al., 2014, T2-T3), found a significant association whereas Gallagher et al. $(2014, \mathrm{~T} 1-\mathrm{T} 3)$ did not. The remaining three studies employed either a one- (McGraw et al., 2008) or three-item (Kleiman et al., 2017, Study 1; Kleiman et al., 2017, Study 2) non-validated suicidal ideation measure. Of these studies, only McGraw et al. (2008) identified loneliness to be a significant predictor of SIB. Overall, 12 of the 17 studies that measured suicidal ideation found loneliness to be a significant predictor, however this reduced to ten studies once some studies controlled for other factors (see section 3.1.4).

\subsubsection{Suicidal Behaviour Measures}

Suicidal behaviour was measured in seven studies in this review (see table 2) with a total of six different measures. Five studies measured attempts to die by suicide (Groholt et al., 2006; Salzinger 
et al., 2007; Schinka et al., 2013; Trakhtenbrot et al., 2016; Wichstrøm, 2009), Schinka et al. (2013) was the only study to measure both suicide attempt and self-harm using one question while Wichstrøm (2009) measured these separately with one question each. All studies used self-report measures with the exception of Junker et al. (2017) and Trakhtenbrot et al. (2016) who used hospital records. No studies included suicide death as an independent outcome measure. Of the seven studies to measure suicidal behaviour, three identified a significant association; this included the three studies where self-harm was included as an outcome variable (Junker et al., 2017; Nickel et al., 2006; Wichstrøm, 2009). These three studies also had among the largest sample sizes and were based in Europe.

\subsubsection{Loneliness Measures}

Ten measures of loneliness were utilised across the studies included in this review. Six studies employed a single-item loneliness assessment; either an unvalidated one-word ecological monetary assessment (EMA; Kleiman et al., 2017, Study 1; Kleiman et al., 2017, Study 2), an unvalidated singleitem question (Junker et al., 2017; Stolz et al. 2016), or used a validated item from a wider psychometric measure (Ayalon and Shiovitz-Ezra., 2011; Nickel et al., 2006). Only studies which used EMA (Kleiman et al., 2017, Study 1; Kleiman et al., 2017, Study 2) did not identify loneliness to significantly predict later SIB.

The four studies (9 results; Fulginiti et al., 2018; Gallagher et al., 2014, Salzinger et al., 2007; Schinka et al., 2013) which utilised the Loneliness and Social Dissatisfaction Questionnaire (LSDQ), all recruited participants aged $\leq 18$ years in the USA. Only Gallagher et al. (2014, T1-T2) found a significant association between baseline loneliness and later SIB.

Ten studies (11 results) used a form of the UCLA Loneliness scale of which eight results reported a significant association (Bennardi et al., 2019; Bonner and Rich, 1988; Hom et al., 2019, T1-T3; Hom et al., 2019, T2-T3; Joiner and Rudd, 1996; Lasgaard et al., 2011; McGraw, 2008; Wichstrøm, 2009). Neither of the studies from Israel (based on psychiatric inpatient or veteran ex-prisoner of war populations), or from a Norwegian hospital (Groholt et al., 2006) found a significant loneliness-SIB association, while all studies which recruited from the general population in other countries did. The remaining two studies used the De Jong Gierveld Loneliness Scale (Joling et al., 2018) or the Short Loneliness Scale (Pietrzak et al., 2017) and both identified loneliness as a significant predictor of suicidal ideation.

\subsubsection{Sample Size}

Sample sizes in the selected studies ranged from 36 (Kleiman et al., 2017, Study 2) to 12,107 (Ayalon and Shiovitz-Ezra, 2011) with the median sample size across the studies being 291 participants. 
Sample sizes $\geq 186$ participants had a tendency be more associated with a significant loneliness-SIB association.

\subsubsection{Generalisability of Sample Population}

Six studies stated that their study sample was generalizable to the target population (Bennardi et al., 2019; Fulginiti et al., 2018; Joiner and Rudd, 1996; Junker et al., 2017; Lasgaard et al., 2011; McGraw et al., 2008). However, these studies also reported significant participant attrition (>40\%). A further four studies (Bonner and Rich, 1988; Pietrzak et al., 2017; Salzinger et al., 2007; Schinka et al., 2013), either reported significant participant attrition (>40\%) or did not comment on attrition in their study. Nickel et al. (2006) and Salzinger et al. (2007) reported that their samples did not reflect their target populations. As three quarters of the studies included in this review were not likely to be representative of their target populations, the findings from these papers may not be generalisable to their respective populations.

\subsubsection{Recruitment site: Geography}

11 of the 14 studies which recruited exclusively from the general population identified loneliness as a significant predictor of later suicidal ideation (Ayalon and Shiovitz-Ezra, 2011; Bennardi et al., 2019; Bonner and Rich, 1988; Hom et al., 2019; Joiner and Rudd et al, 1996; Joling et al., 2018; Lasgaard et al., 2011; McGraw et al., 2008; Stolz et al., 2016) or behaviour (Junker et al., 2017; Wichstrøm, 2009). Of the three general population-based studies which did not identify loneliness as a significant predictor, two were from the United States (Salzinger et al., 2007; Schinka et al., 2013) and two contained sample sizes significantly below the median (Kleiman et al., 2017, Study 1; Salzinger et al., 2007).

Of the three studies ( 4 results) which recruited exclusively from psychiatric inpatient populations only Gallagher et al. (2014, T2-T3) found that loneliness was a significant predictor of later SIB. Additionally, Nickel (2006) recruited a combination of inpatient, outpatient and community-based participants with a larger sample size and identified loneliness as a significant predictor of later suicidal behaviour. Pietrzak et al. (2017) and Stein et al. (2017) both recruited from veteran populations with contrasting results, however the heterogeneity of those studies made it impossible to infer the reasons for the conflicting findings.

\subsubsection{Follow-Up Duration}

Follow-up duration ranged from an average of seven days (Kleiman et al., 2017, Study 2) to 12 years (Stein et al., 2017). Loneliness was commonly found to be a significant predictor of SIB between one month to five years after baseline loneliness assessment (Ayalon and Shiovitz-Ezra, 2011; Bennardi et al., 2019; Bonner and Rich, 1988; Fulginiti et al., 2018; Gallagher et al., 2014; Hom et al., 2019; Joiner and Rudd, 1996; Joling et al., 2018; Lasgaard et al., 2011; McGraw, 2008; Nickel et al., 2006; 
Pietrzak et al., 2017; Stolz et al., 2016; Wichstrøm, 2009). Of the 18 results within this timespan, only four results were not significant (Fulginiti et al., 2018; Gallagher et al., 2014, T1-T3; Schinka et al., 2013, T2-T3 ideation; Schinka et al., 2013, T2-T3 behaviour). Commonalities between these nonsignificant results included the recruitment of some of the youngest participants within this review and all studies used the LSDQ measure for loneliness. Only two of the studies with follow-ups of less than a month (Kleiman et al., 2017, Study 1; Kleiman et al., 2017, Study 2) yielded non-significant results, while only one study (Junker at al., 2017) of the six which measured beyond five years found a significant result. A distinguishing feature of Junker et al. (2017) was that they recruited significantly more participants than the other studies where follow-up was out-with the 1 month-5year timeframe.

\subsection{Meta-analysis}

17 studies were included within the meta-analysis to explore the association between loneliness and later SIB. However as there were differences in data availability across the studies, the number of studies reported within each section of the meta-analysis varies.

The meta-analytic findings are described as follows:

i. Identification of a loneliness-SIB relationship

ii. Methodological quality

iii. Moderating effects of socio-demographic characteristics (age, gender) on to the lonelinessSIB relationship;

iv. The role of depression as a mediator of the loneliness-SIB relationship;

\subsubsection{Association between loneliness and SIB}

Effect sizes for the overall study samples were entered into the meta-analysis irrespective of whether the outcome was ideation, self-harm or suicide attempts. To prevent over-representation of study samples, overall effect sizes were calculated for studies where loneliness was measured at more than one timepoint. This resulted in 17 studies with one effect size calculated for each study. With the exception of both Bennardi et al. (2019) who controlled for multiple demographics and health factors, and Junker et al. (2017) who controlled for age, all effect sizes were unadjusted. A random effects model illustrated that loneliness was a significant predictor of later SIB ( $r=0.2195 \%$ $\mathrm{Cl} ; 0.14-0.28, z=5.97, p<0.001)$. Although there was significant statistical heterogeneity across the studies $\left(I^{2}=97.5 \%\right.$, Cochrane Q: $\left.647.501 p<0.001\right)$, there was no publication bias (Classic Fail-Safe $N=$ 4473; $z$-value $=31.84998, p<0.00001$ ) as illustrated by the funnel plot in Figure 3 . Two papers (Salzinger et al.,2007; Schinka et al.,2013) measured both suicidal ideation and behaviour as outcome variables. To avoid over-representation, these papers were excluded from the moderation 
analysis to explore any statistical difference between loneliness predicting suicidal ideation compared to behaviour. Moderation analysis revealed that the effect sizes for suicidal ideation and behaviour were significantly different $(Q(1)=181.566, p<0.001)$ with fixed effects models showing that that loneliness was a stronger predictor of suicidal behaviour $(r=0.28,95 \% \mathrm{Cl}: 0.23-0.3, p<0.001$, $\mathrm{n}=6$ studies) than suicidal ideation ( $\mathrm{r}=0.16,95 \% \mathrm{Cl}: 0.15-0.17, \mathrm{p}<0.001, \mathrm{n}=13$ studies $)$

\section{INSERT FIGURES 2 \& 3 HERE}

\subsubsection{Methodological quality}

Moderation analysis indicated that the quality assessment score was not a statistically significant moderator of the loneliness-SIB relationship.

\subsubsection{Moderating effect of age}

13 studies provided sufficient data to explore whether age moderated the association between loneliness and SIB. Moderation analysis indicated that age did not statistically affect the loneliness and later SIB relationship. However, there was a dearth of studies covering mid-life ( 25 to 55 years; see Figure 4).

\section{Insert Figure 4 here}

\subsubsection{Moderating effect of gender}

All 17 studies were included in the moderation analysis to explore loneliness predicting SIB as a function of gender. Overall, fixed-effects moderation analysis indicated that in the majority female studies ( $n=13$ studies) loneliness accounted for $15.5 \%$ of the variance in later SIB (95\% Cl 0.144 , $0.167, p<0.001)$ whereas in majority male studies $(n=4)$ loneliness accounted for $34.4 \%$ of the SIB variance $(95 \% \mathrm{Cl} 0.327,0.360, \mathrm{p}<0.001)$. However, there was significant heterogeneity across both groups of studies $(Q(15)=314.884, p<0.001)$ and a mixed effects model showed there was no significant difference between the dichotomised groups (males vs females) or when gender was reported as a continuous variable (percentage of sample being female).

\section{Insert Figure 5 here}

\subsection{Depression as a mediator of loneliness and later SIB}

16 studies were available to explore whether depression mediated the association between loneliness and later SIB (see Appendix 3 for a list of included studies). For studies with multiple results, a single correlation value was calculated between each combination pair of the three variables (loneliness, depression, SIB). Models were run from a correlation matrix and specified in MPlus 8.4 (Muthén and Muthén, 2017) using maximum likelihood estimation. Of the 16 papers that 
were included in the present analysis, the number of studies from which data were provided was as follows; associations between loneliness and depression $(N=6)$, depression and SIB $(N=11)$ and loneliness and SIB $(N=16)$. Based on this the following estimates were entered into the metaanalytic mediation model: (1) the average association between loneliness and depression $(r=.3617)$, depression and SIB $(r=.3227)$ and loneliness and SIB $(r=.1713)$. The sample sizes ranged from 78 to 12,107 , the median sample size was 387 and the average was 1862. Based on the average sample size the relationships between loneliness and depression $(\beta=0.362, p<0.001)$, depression and SIB $(\beta=0.300, p<0.001)$ and loneliness and $\operatorname{SIB}(\beta=0.063, p=.007)$ were all significant as was the indirect effect from loneliness to SIB via depression $(\beta=0.109, p<0.0001)$. Based on the median sample size the relationship between loneliness and depression and depression and SIB remained significant but loneliness and suicide ideation/behaviour was now non-significant. However, there was still a significant indirect effect from loneliness to SIB via depression $(\beta=0.109, p<.0001)$.

\section{Discussion}

This review aimed to synthesise findings from existing studies pertaining to whether loneliness predicted later SIB, and if so, whether socio-demographic factors were associated with this relationship or depression acted as a mediator. Of the 22 studies (28 results) that met review criteria, 14 studies (15 results) found that loneliness was a significant predictor of later SIB. There was also evidence that depression mediated the loneliness and later SIB relationship. Of all studies considered within the narrative component of the review, the loneliness-SIB association was more frequently observed in studies that were predominantly female in composition and age-dependent effects were evident.

The finding that loneliness predicted later SIB fits with several theories of the emergence of SIB. For example, the IMV model (O'Connor and Kirtley, 2018) argues that loneliness may act similarly to social isolation which is included in the model. If so, loneliness may act as a motivational phase factor; increasing the likelihood that entrapment, a key precursor of suicidal ideation, develops. The Interpersonal Theory of Suicide (ITS; Van Orden et al., 2010) also suggests that loneliness in the form of thwarted belongingness is an important predictor of suicidal behaviour.

Loneliness was more strongly associated with SIB in the longer term compared to in the short-term. This may relate to the stability of loneliness, if present over long time being more pernicious, although this requires more detailed investigation. The moderation analysis revealed that loneliness was a stronger predictor of suicidal behaviour than of suicidal ideation. It is important to note though, that although suicide attempts were assessed in many of the studies, no study measured suicide death. Additionally, the potential lethality or suicidal intent of the suicidal acts were not investigated in the review. The meta-analysis also found that depression mediated the relationship 
between loneliness and later SIB. Further research is required to determine the potential mechanisms through which loneliness may lead to depression.

Of the subsample of studies included in the moderation analysis exploring gender as a moderator of loneliness and SIB, no statistically significant difference was identified. However, when considering all studies included this review, a large majority of studies comprising of mainly female participants identified loneliness as a predictor of later SIB compared to male-dominant studies which remained at chance-level. However, it is important to note that the male participants were particularly underrepresented in this review. Despite this, any potential gender differences may be affected by social stigma which is associated with self-reporting loneliness in male populations (Borys and Perlman, 1985; Nicolaisen and Thorsen, 2014), with those of Western countries reportedly being less accepting of men disclosing loneliness. Nicolaisen and Thorsen (2014) suggested that the De Jong Gierveld measures may be the only studies to detect gender differences due to their assessment of social and emotional loneliness seperately, however only one study here used the scale and did not explore gender differences. Finally, all studies in the review reported gender on a binary scale, which may have affected the findings. Future research investigating the loneliness-SIB relationship may benefit from reporting the loneliness-SIB relationship in non-binary populations when capturing demographic information.

With regard to age, observations made in this review supported existing research (Victor and Yang, 2012 ) in that the loneliness-SIB relationship was more likely to be identified in those aged 16-20 or $>58$ years at baseline, thereby suggestive of a U-shaped trend. It may be that these two age groups coincide with when loneliness peaks across the lifespan as major transitions in social status occur: school graduate (e.g. student to young adult/ labour market) and working adult to retiree. Nicolaisen and Thorsen (2014) argue that at these social transition timepoints, individuals spend more time focusing on their next role in society, thereby loosening ties with existing social supports (e.g. school friends, colleagues). As the transition progresses, new bonds are established and the maintenance of former social bonds become more difficult. If these new bonds are not formed, or social identity is not suitably adjusted, this may create an opportunity for loneliness to develop. Despite this age-related trend, two studies (Ayalon and Shiovitz-Ezra, 2011; Bennardi et al., 2019) noted a 'drop-off' in the loneliness-SIB relationship in adults aged approximately 65 years old. It could be argued that the transition from working adult to retiree had already happened for those aged $>65$ years old, where these populations had already adjusted to their new role in society, leading to this loss in the loneliness-SIB association. Both Ayalon and Shiovitz-Ezra (2011) and Bennardi et al. (2019) postulated this observation was perhaps due to loneliness being considered 'an on-time event' (Ayalon and Shiovitz-Ezra, 2011) due to the limitations associated with older age 
(e.g. diminishing social life, the death of older and frailer friends and family, one's own limited health and mobility) while trying to maintain a social life.

Commonalities across studies were also observed in terms of geography. Most of studies in this review were from Europe or from the United States, however virtually all of the European studies found a significant relationship between loneliness and later SIB while USA-based results were more variable. Research comparing the prevalence of loneliness across continents is limited, therefore there is little room for speculation regarding observed or hypothesised differences. Despite this, it is important to highlight that the European-based studies often had larger sample sizes than other countries in this review, as well as having more female-dominant sample populations. The findings here suggest the loneliness-SIB relationship is more detectable in studies with larger participant sample sizes (potential small effects). However, as females were over-represented in this review and the range of geographical locations of studies was limited, it is not yet possible to infer whether geography or gender moderate the relationship between loneliness and SIB. Lastly, while most studies used interviews or paper questionnaires to assess the key measures, two studies used EMA (Kleiman et al., 2017, Study 1; Kleiman et al., 2017, Study 2) and these were outliers in respect of trends observed (e.g. gender and follow-up duration). Thus, the mode of measurement may influence whether a loneliness -SIB relationship is detected. Therefore, future research is required to better understand whether EMA studies of loneliness are exploring something different from traditional study measurement scales.

\subsection{Limitations}

The considerable heterogeneity across the studies means that the aggregate findings discussed here should be interpreted with caution. Although this review finds evidence that loneliness may predict SIB, the definition of suicidal behaviour and its constituent terms (e.g. self-harm, suicide attempt) varied considerably between studies (as illustrated by Nickel et al., 2006 see Appendix 1).

Furthermore, no studies included suicide death as a distinct outcome measure. For example, although Groholt et al. (2006) excluded participants who were deceased at follow-up, their study did include two participants who died by suicide. Meanwhile Trakhtenbrot et al. (2016) included all participants who died by suicide within their suicide attempt group but did not make any comparisons between those who had died or survived. These limitations prevent this review from fully exploring the extent to which loneliness predicts SIB in relation to the full range of suicide attempt outcomes. However, this does illustrate that suicide death as an outcome variable is lacking in the extant literature.

With regard to predictors of a loneliness-SIB association, female-dominant studies typically had larger participant sample sizes and were usually based in Europe. Observationally, these three 
features (gender, locality and sample size) were consistently associated with identifying a significant relationship between loneliness and later SIB so it is not possible to distinguish which of these elements is the most influential. Meta-analysis did not reveal any of these features to influence the loneliness-later SIB association, however certain factors must be considered when interpreting these results. For example, male populations were under-represented in this review. Furthermore, studies with a participant baseline age of less than 18 years old accounted for half of the results considered here, and no study with a mean participant age between 24 and 55 provided sufficient data to be included in a meta-analysis investigating age as a moderator.

Finally, an exclusion criterion for this review was that studies must have been available in English, therefore not all published works on the topic of loneliness in relation to later SIB may have been included. This may be reflected by the absence of studies based in Asia or Africa, where papers on this topic may have been written in a non-English language. Additionally, all studies were from Western countries where self-reliance and independence (i.e. individualism) is the cultural norm. Research indicates that when compared to collectivism, individualism is a protective factor against loneliness (Lykes and Kemmelmeier, 2014), which would suggest that the loneliness-SIB relationship may be stronger in countries not addressed in this review. Due to the lack of collectivist countries included in this review, comparisons could not be made to identify whether these results were limited to individualistic populations or were internationally applicable.

\subsection{Conclusion}

In conclusion, loneliness was shown to predict future SIB in both the narrative review and metaanalysis. There was evidence of a loneliness and later SIB relationship among those aged 16 to 20 years, or over 58 years at baseline and in participant samples that were predominantly female. However, these differential relationships were not supported by moderation analyses in a subsample of the studies. Mediation analysis found that depression acted as a mediator of the loneliness to later SIB relationship. Finally, it was observed that loneliness was particularly predictive of later SIB in the short to medium term (up to five years). No prospective studies specifically measured suicide death as an outcome measure and future research would benefit from studying more collectivist cultures. 


\section{References}

Achenbach, T.M., 1991. Manual for the youth self-report and 1991 profile. Department of Psychiatry, University of Vermont Burlington, VT.

Achenbach, T.M., 1992. Manual for the Child Behavior Checklist/2-3 and 1992 profile. Department of Psychiatry, University of Vermont.

Asher, S.R., Hymel, S., Renshaw, P.D., 1984. Loneliness in Children. Child Development 55, 1456 1464.

Averbeck, M., Leiberich, P., Grote-Kusch, M., Olbrich, E., Schröder, A., Brieger, M., Schumacher, K., 1997. SEL; Skalen zur Erfassung der Lebensqualität. Frankfurt aM: Swets \& Zeitlinger BV (Swets Test Services).

Ayalon, L.S.-E., Sharon, 2011. The relationship between loneliness and passive death wishes in the second half of life. International Psychogeriatrics 23, 1677-1685.

Batigun, A.D., 2005. Suicide probability: An assessment terms of reasons for living, hopelessness and loneliness. Turk Psikiyatri Dergisi 16, 29-39.

Beck, A.T., Steer, R.A., Carbin, M.G., 1988. Psychometric properties of the Beck Depression Inventory: Twenty-five years of evaluation. Clinical Psychology Review 8, 77-100.

Bennardi, M., Caballero, F.F., Miret, M., Ayuso-Mateos, J.L., Haro, J.M., Lara, E., Arensman, E., Cabello, M., 2019. Longitudinal Relationships Between Positive Affect, Loneliness, and Suicide Ideation: Age-Specific Factors in a General Population. Suicide and Life-Threatening Behavior 49, 90103.

Beutel, M.E., Klein, E.M., Brähler, E., Reiner, I., Jünger, C., Michal, M., Wiltink, J., Wild, P.S., Münzel, T., Lackner, K.J., Tibubos, A.N., 2017. Loneliness in the general population: Prevalence, determinants and relations to mental health. BMC Psychiatry 17.

Bondevik, M., Skogstad, A., 1998. The Oldest Old, ADL, Social Network, and Loneliness. Western Journal of Nursing Research 20, 325-343.

Bonner, R. L., \& Rich, A. R. (1988). A prospective investigation of suicidal ideation in college students: A test of a model. Suicide and Life-Threatening Behavior, 18(3), 245-258.

Borys, S., Perlman, D., 1985. Gender differences in loneliness. Personality and Social Psychology Bulletin 11, 63-74.

British Red Cross, 2016. Trapped in a bubble: An investigation into triggers for loneliness in the UK. Cacioppo, J.T., Hughes, M.E., Waite, L.J., Hawkley, L.C., Thisted, R.A., 2006. Loneliness as a specific risk factor for depressive symptoms: cross-sectional and longitudinal analyses. Psychology and aging $21,140$.

Calati, R., Ferrari, C., Brittner, M., Oasi, O., Olié, E., Carvalho, A. F., \& Courtet, P. (2019). Suicidal thoughts and behaviors and social isolation: A narrative review of the literature. Journal of affective disorders, 245, 653-667.

Chang, Q., Chan, C.H., Yip, P.S.F., 2017. A meta-analytic review on social relationships and suicidal ideation among older adults. Social Science \& Medicine 191, 65-76.

Comprehensive Meta-Analysis Version 3 Borenstein, M., Hedges, L., Higgins, J., \& Rothstein, H. Biostat, Englewood, NJ 2013

Cull, J.G., Gill, W.S., 1989. Suicide probability scale (SPS). Los Angeles: Western Psychological Services.

de Jong-Gierveld, J., Kamphuls, F., 1985. The development of a Rasch-type loneliness scale. Applied psychological measurement 9, 289-299.

De Jong Gierveld, J., Van Tilburg, T., 2010. The De Jong Gierveld short scales for emotional and social loneliness: tested on data from 7 countries in the UN generations and gender surveys. European Journal of Ageing 7, 121-130.

Derogatis, L.R., Cleary, P.A., 1977. Confirmation of the dimensional structure of the scl-90: A study in construct validation. Journal of Clinical Psychology 33, 981-989. 
Franklin, J.C., Ribeiro, J.D., Fox, K.R., Bentley, K.H., Kleiman, E.M., Huang, X., Musacchio, K.M., Jaroszewski, A.C., Chang, B.P., Nock, M.K., 2017. Risk factors for suicidal thoughts and behaviors: a meta-analysis of 50 years of research. Psychological Bulletin 143, 187.

Fulginiti, A., He, A. S., \& Negriff, S. (2018). Suicidal because I don't feel connected or vice versa? A longitudinal study of suicidal ideation and connectedness among child welfare youth. Child abuse \& neglect, 86, 278-289.

Gallagher, M., Prinstein, M. J., Simon, V., \& Spirito, A. (2014). Social anxiety symptoms and suicidal ideation in a clinical sample of early adolescents: Examining loneliness and social support as longitudinal mediators. Journal of abnormal child psychology, 42(6), 871-883.

Groholt, B., Ekeberg, $\varnothing$., \& Haldorsen, T. (2006). Adolescent suicide attempters: what predicts future suicidal acts?. Suicide and Life-Threatening Behavior, 36(6), 638-650.

Hawton, K., Casañas i Comabella, C., Haw, C., Saunders, K., 2013. Risk factors for suicide in individuals with depression: A systematic review. Journal of Affective Disorders 147, 17-28. Hedley, D., Uljarević, M., Foley, K.-R., Richdale, A., Trollor, J., 2018. Risk and protective factors underlying depression and suicidal ideation in Autism Spectrum Disorder. Depression And Anxiety. HM Government, 2018. A connected society: a strategy for tackling loneliness, in: Department for Digital, C., Media and Sport (Ed.). Crown copyright.

Holt-Lunstad, J., Smith, T.B., Baker, M., Harris, T., Stephenson, D., 2015. Loneliness and Social Isolation as Risk Factors for Mortality:A Meta-Analytic Review. Perspectives on Psychological Science 10, 227-237.

Hom, M. A., Stanley, I. H., Chu, C., Sanabria, M. M., Christensen, K., Albury, E. A., ... \& Joiner, T. E. (2019). A Longitudinal Study of Psychological Factors as Mediators of the Relationship Between Insomnia Symptoms and Suicidal Ideation Among Young Adults. Journal of clinical sleep medicine: JCSM: official publication of the American Academy of Sleep Medicine, 15(1), 55-63.Hughes, M.E., Waite, L.J., Hawkley, L.C., Cacioppo, J.T., 2004. A Short Scale for Measuring Loneliness in Large Surveys: Results From Two Population-Based Studies. Research on Aging 26, 655-672.

Joiner, T.E., Jr., Rudd, M.D., 1996. Disentangling the interrelations between hopelessness, loneliness, and suicidal ideation. Suicide \& Life-Threatening Behavior 26, 19-26.

Joiner Jr, T. E., Pfaff, J. J., \& Acres, J. G. (2002). A brief screening tool for suicidal symptoms in adolescents and young adults in general health settings: reliability and validity data from the Australian National General Practice Youth Suicide Prevention Project. Behaviour research and therapy, 40(4), 471-481.

Joling, K.J., O'Dwyer, S.T., Hertogh, C.M.P.M., van Hout, H.P.J., 2018. The occurrence and persistence of thoughts of suicide, self-harm and death in family caregivers of people with dementia: a longitudinal data analysis over 2 years. International Journal of Geriatric Psychiatry 33, 263-270. Junker, A., Bjørngaard, J.H., Bjerkeset, O., 2017. Adolescent health and subsequent risk of self-harm hospitalisation: a 15-year follow-up of the Young-HUNT cohort. Child And Adolescent Psychiatry And Mental Health 11, 25-25.

Kessler, R.C., Üstün, T.B., 2004. The World Mental Health (WMH) Survey Initiative version of the World Health Organization (WHO) Composite International Diagnostic Interview (CIDI). International Journal of Methods in Psychiatric Research 13, 93-121.

Kleiman, E.M., Turner, B.J., Fedor, S., Beale, E.E., Huffman, J.C., Nock, M.K., 2017a. Examination of real-time fluctuations in suicidal ideation and its risk factors: Results from two ecological momentary assessment studies. Journal of Abnormal Psychology 126, 726-738.

Kleiman, E.M., Turner, B.J., Fedor, S., Beale, E.E., Huffman, J.C., Nock, M.K., 2017b. Examination of Real-Time Fluctuations in Suicidal Ideation and Its Risk Factors: Results From Two Ecological Momentary Assessment Studies. Journal of Abnormal Psychology 126, 726-738.

Kleiman, E.M.T., Brianna J.; Fedor, Szymon; Beale, Eleanor E.; Huffman, Jeff C.; Nock, Matthew K., 2017. Examination of Real-Time Fluctuations in Suicidal Ideation and Its Risk Factors: Results From Two Ecological Momentary Assessment Studies. Journal of Abnormal Psychology 126, 726-738. Kovacs, M., Preiss, M., 1992. CDI. Children's Depression Inventory Multi-Health Systems. New York. 
Lasgaard, M., Goossens, L., Elklit, A., 2011. Loneliness, Depressive Symptomatology, and Suicide Ideation in Adolescence: Cross-Sectional and Longitudinal Analyses. Journal of Abnormal Child Psychology 39, 137-150.

Loneliness Taskforce, 2018. A Connected Island; An Ireland Free From Loneliness. Loneliness Taskforce.

Lovibond, P.F., Lovibond, S.H., 1995. The structure of negative emotional states: Comparison of the Depression Anxiety Stress Scales (DASS) with the Beck Depression and Anxiety Inventories. Behaviour Research and Therapy 33, 335-343.

Lykes, V.A., Kemmelmeier, M., 2014. What Predicts Loneliness? Cultural Difference Between Individualistic and Collectivistic Societies in Europe. Journal of Cross-Cultural Psychology 45, 468490.

Maes, M., Qualter;, P., V., J., V.D.N., W., G., L., 2019. Gender differences in loneliness in children and adolescents: A meta-analysis. Biennial meeting of the Society for Research in Child Development. Mars, B., Heron, J., Klonsky, E.D., Moran, P., O'Connor, R.C., Tilling, K., Wilkinson, P., Gunnell, D., 2019. Predictors of future suicide attempt among adolescents with suicidal thoughts or non-suicidal self-harm: a population-based birth cohort study. The Lancet Psychiatry 6, 327-337.

McGraw, K.M., Susan; Fuller, Andrew; Bates, Glen, 2008. Family, peer and school connectedness in final year secondary school students. Australian Psychologist 43, 27-37.

Metalsky, G., 1991. The depressive symptom index. Unpublished manuscript.

Moher, D., Shamseer, L., Clarke, M., Ghersi, D., Liberati, A., Petticrew, M., Shekelle, P., Stewart, L.A., Group, P.-P., 2015. Preferred reporting items for systematic review and meta-analysis protocols (PRISMA-P) 2015 statement. Systematic Reviews 4, 1.

Mushtaq, R., Shoib, S., Shah, T., Mushtaq, S., 2014. Relationship between loneliness, psychiatric disorders and physical health ? A review on the psychological aspects of loneliness. J Clin Diagn Res 8, WE01-WE04.

Muthén, L. K., \& Muthén, B. O. (1998-2017). Mplus User's Guide. Eigth Edition. Los Angeles, CA: Muthén \& Muthén.

National Institute for Health and Care Excellence (NICE), 2011. Self-harm in over 8s: long-term management.

Nickel, M.K.S., M.; Lojewski, N.; Muehlbacher, M.; Fartacek, R.; Kettler, C.; Bachler, E.; Egger, C.; Rother, N.; Buschmann, W.; Gil, F. P.; Kaplan, P.; Mitterlehner, F. O.; Anvar, J.; Rother, W. K.; Loew, T. H.; Nickel, C., 2006. Familial and socilopsychopathological risk factors for suicide attempt in bulilmic and in depressed women: Prospective study. International Journal of Eating Disorders 39, 410-417. Nicolaisen, M., Thorsen, K., 2014. Who are Lonely? Loneliness in Different Age Groups (18-81 Years Old), Using Two Measures of Loneliness. The International Journal of Aging and Human Development 78, 229-257.

Nock, M.K., Prinstein, M.J., 2005. Contextual Features and Behavioral Functions of Self-Mutilation Among Adolescents. Journal of Abnormal Psychology 114, 140-146.

O'Connor, R., 2011. Towards an Integrated Motivational-Volitional Model of Suicidal Behaviour. O'Connor, R.C., Kirtley, O.J., 2018. The integrated motivational-volitional model of suicidal behaviour. Philosophical Transactions of the Royal Society B: Biological Sciences 373, 20170268. O'Connor, R.C.,Wetherall, K., Cleare, S., Eschle, S., J. Drummond, Ferguson, E., O'Connor, D.B., O'Carroll, R. (2018). Suicide attempts and non-suicidal self-harm: a national prevalence study of young adults. British Journal of Psychiatry Open, 4, 142-148.

Perlman, D., Peplau, L.A., 1981. Toward a social psychology of loneliness. Personal relationships 3, 31-56.

Office for National Statistics- Suicide in the UK: 2018 Registrations. 3rd Septmeber 2019. URL: https://www.ons.gov.uk/peoplepopulationandcommunity/birthsdeathsandmarriages/deaths/bulleti $\mathrm{ns} /$ suicidesintheunitedkingdom/2018registrations

Pietrzak, R.H., Pitts, B.L., Harpaz-Rotem, I., Southwick, S.M., Whealin, J.M., 2017. Factors protecting against the development of suicidal ideation in military veterans. World Psychiatry 16, 326-327. 
Prince, M.J., Reischies, F., Beekman, A.T.F., Fuhrer, R., Jonker, C., Kivela, S.L., Lawlor, B.A., Lobo, A., Magnusson, H., Fichter, M., Van Oyen, H., Roelands, M., Skoog, I., Turrina, C., Copeland, J.R.M., 1999. Development of the EURO-D scale - a European Union initiative to compare symptoms of depression in 14 European centres. British Journal of Psychiatry 174, 330-338.

Qualter, P., Vanhalst, J., Harris, R., Van Roekel, E., Lodder, G., Bangee, M., Maes, M., Verhagen, M., 2015. Loneliness Across the Life Span. Perspectives on Psychological Science 10, 250-264.

Qualter, P.B., Stephen L.; Munn, Penny; Rotenberg, Ken J., 2010. Childhood loneliness as a predictor of adolescent depressive symptoms: an 8-year longitudinal study. European Child \& Adolescent Psychiatry 19, 493-501.

Radloff, L.S., 1977. The CES-D Scale: A Self-Report Depression Scale for Research in the General Population. Applied Psychological Measurement 1, 385-401.

Russell, D., Peplau, L.A., Cutrona, C.E., 1980. The revised UCLA Loneliness Scale: Concurrent and discriminant validity evidence. Journal of personality and social psychology 39, 472.

Russell, D., Peplau, L.A., Ferguson, M.L., 1978. Developing a measure of loneliness. Journal of personality assessment 42, 290-294.

Russell, D.W., 1996. UCLA Loneliness Scale (Version 3): Reliability, Validity, and Factor Structure. Journal of Personality Assessment 66, 20-40.

Salzinger, S., Rosario, M., Feldman, R.S., Ng-Mak, D.S., 2007. Adolescent suicidal behavior: Associations with preadolescent physical abuse and selected risk and protective factors. Journal of the American Academy of Child \& Adolescent Psychiatry 46, 859-866.

Schinka, K.C., van Dulmen, M.H.M., Mata, A.D., Bossarte, R., Swahn, M., 2013. Psychosocial predictors and outcomes of loneliness trajectories from childhood to early adolescence. Journal of Adolescence 36, 1251-1260.

Spitzer, R.L., Kroenke, K., Williams, J.B.W., Group, a.t.P.H.Q.P.C.S., 1999. Validation and Utility of a Self-report Version of PRIME-MDThe PHQ Primary Care Study. JAMA 282, 1737-1744.

Stein, J.Y., Itzhaky, L., Levi-Belz, Y., Solomon, Z., 2017. Traumatization, Loneliness, and Suicidal Ideation among Former Prisoners of War: A Longitudinally Assessed Sequential Mediation Model. Frontiers In Psychiatry 8, 281-281.

Stickley, A., Koyanagi, A., 2016. Loneliness, common mental disorders and suicidal behavior: Findings from a general population survey. Journal Of Affective Disorders 197, 81-87.

Stokes, J.P., Levin, I., 1986. Gender differences in predicting loneliness from social network characteristics. Journal of Personality and Social Psychology 51, 1069.

Stolz, E., Fux, B., Mayerl, H., Rásky, É., Freidl, W., 2016. Passive Suicide Ideation Among Older Adults in Europe: A Multilevel Regression Analysis of Individual and Societal Determinants in 12 Countries (SHARE). Journals of Gerontology Series B: Psychological Sciences \& Social Sciences 71, 947-958.

Strand, B.H., Dalgard, O.S., Tambs, K., Rognerud, M., 2003. Measuring the mental health status of the Norwegian population: A comparison of the instruments SCL-25, SCL-10, SCL-5 and MHI-5 (SF36). Nordic Journal of Psychiatry 57, 113-118.

Stravynski, A., Boyer, R., 2001. Loneliness in relation to suicide ideation and parasuicide: A population-wide study. Suicide and Life-Threatening Behavior 31, 32-40.

Teo, A.R., Marsh, H.E., Forsberg, C.W., Nicolaidis, C., Chen, J.I., Newsom, J., Saha, S., Dobscha, S.K., 2018. Loneliness is closely associated with depression outcomes and suicidal ideation among military veterans in primary care. Journal of Affective Disorders 230, $42-49$.

Thastum, M., Ravn, K., Sommer, S., Trillingsgaard, A., 2009. Reliability, validity and normative data for the Danish Beck Youth Inventories. Scandinavian Journal of Psychology 50, 47-54.

The World Bank, 2019. World Bank staff estimates based on age/sex distributions of United Nations Population Division's World Population Prospects: 2017 Revision, in: Bank, T.W. (Ed.).

Trakhtenbrot, R., Gvion, Y., Levi-Belz, Y., Horesh, N., Fischel, T., Weiser, M., Treves, I., Apter, A., 2016. Predictive value of psychological characteristics and suicide history on medical lethality of suicide attempts: A follow-up study of hospitalized patients. Journal Of Affective Disorders 199, 7380. 
Turecki, G., Brent, D.A., 2016. Suicide and suicidal behaviour. The Lancet 387, 1227-1239.

Van Orden, K.A., Witte, T.K., Cukrowicz, K.C., Braithwaite, S.R., Selby, E.A., Joiner, T.E., Jr., 2010. The interpersonal theory of suicide. Psychological Review 117, 575-600.

Vanhalst, J., Luyckx, K., Teppers, E., Goossens, L., 2012. Disentangling the longitudinal relation between loneliness and depressive symptoms: Prospective effects and the intervening role of coping. Journal of Social and Clinical Psychology 31, 810-834.

Victor, C.R., Yang, K., 2012. The prevalence of loneliness among adults: a case study of the United Kingdom. The Journal of psychology 146, 85-104.

Wang, R., Xue, D., Liu, Y., Chen, H., Qiu, Y., 2018. The relationship between urbanization and depression in China: the mediating role of neighborhood social capital. International Journal for Equity in Health 17, 105.

Wetherall, K., Cleare, S., Eschle, S., Ferguson, E., O'Connor, D.B., O'Carroll, R.E., O'Connor, R.C., 2018. From ideation to action: Differentiating between those who think about suicide and those who attempt suicide in a national study of young adults. Journal of affective disorders $241,475-483$. Wichstrøm, L., 2009. Predictors of non-suicidal self-injury versus attempted suicide: Similar or different? Archives of Suicide Research 13, 105-122.

Wong, W.C.W., Cheung, C.S.K., Hart, G.J., 2008. Development of a quality assessment tool for systematic reviews of observational studies (QATSO) of HIV prevalence in men having sex with men and associated risk behaviours. Emerging Themes in Epidemiology 5, 23.

World Health Organization, 2017. World health statistics 2017: monitoring health for the SDGs, Sustainable Development Goals, Geneva, pp. 1-103.

Yang, K., Victor, C., 2011. Age and loneliness in 25 European nations. Ageing and Society 31, 13681388. 
Figure 1. Procedure for identifying applicable studies (screening and determining the eligibility for the current review)

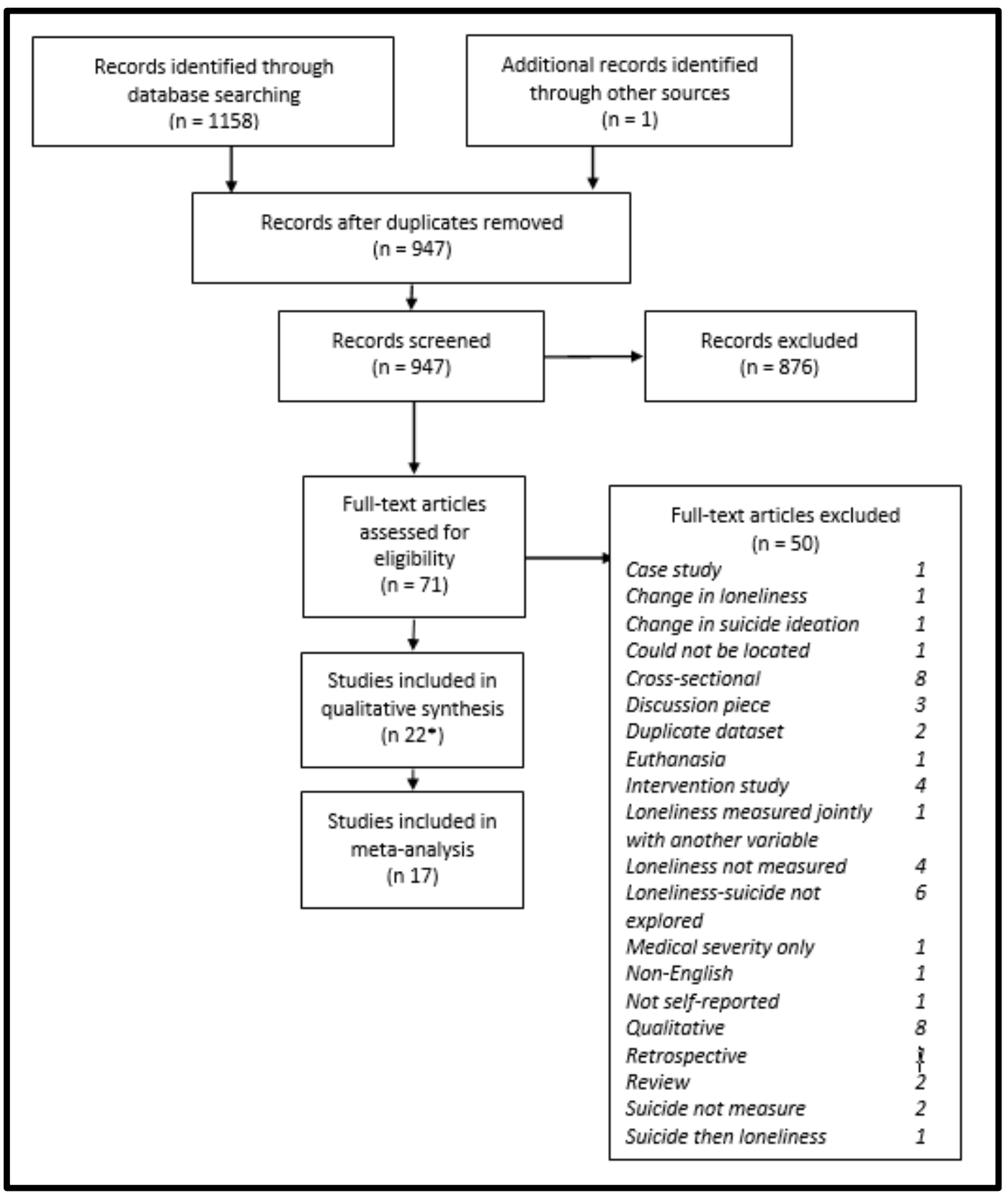

Panel 1: Search Strategy

The databases searched in this review were Web of knowledge, Medline, CINAHL, PsychINFO and PsychArticles with EbscoHost being used to search the last 4 databases mentioned. The search terms were (1(i) lonel* OR "perceived social isolation" OR "perceived social exclusion", AND (ii) suicid* OR "self-injurious" OR "self injurious" OR "self-harm" OR "self harm". Terms were truncated to allow for various terminologies used within the papers. These terms were searched for in all articles of Web of Knowledge and in the abstracts and full articles of academic journals and journals of the remaining 4 databases. This yielded 2484 results which reduced to 1158 when limited to English-only text in all databases. For Medline, PsychInfo, PsychArticles and CINHAL only, the search results were further limited by removing articles classified as a literature review, systematic review, brain imaging, mathematical model, meta-analysis, books and/or scientific simulation. This resulted in a total of 947 studies which were screened visually by the first author, followed by an inter-rater check of $20 \%$ of the papers by a research colleague with $100 \%$ concordance 
Table 1. Quality Assessment Criteria

\begin{tabular}{|c|c|c|c|c|c|c|}
\hline Score & Design & Confounding variables & Attrition & $\begin{array}{l}\text { Validity of predictor } \\
\text { measure }\end{array}$ & Validity of outcome measure & $\begin{array}{l}\text { Included in } \\
\text { meta- } \\
\text { analysis }\end{array}$ \\
\hline 0 & $\begin{array}{l}\text { Opportunity } \\
\text { sampling }\end{array}$ & $\begin{array}{l}\text { No attempt to control } \\
\text { confounding variables } \\
\text { during recruitment or } \\
\text { analysis }\end{array}$ & $\begin{array}{l}\text { Significant } \\
\text { attrition/ loss of } \\
\text { target } \\
\text { population; } \\
\text { Attrition not } \\
\text { reported }\end{array}$ & $\begin{array}{l}\text { Single-item assessment } \\
\text { with no valid or reliable } \\
\text { backing }\end{array}$ & $\begin{array}{l}\text { Unclear assessment of suicidal } \\
\text { ideation or behaviour; } \\
\text { Measure is invalid or unreliable; } \\
\text { Mixed assessment of SIB }\end{array}$ & No \\
\hline 1 & $\begin{array}{l}\text { Representative } \\
\text { samples }\end{array}$ & $\begin{array}{l}\text { Some attempt to control } \\
\text { for confounding variables } \\
\text { (e.g. demographics) }\end{array}$ & $\begin{array}{l}\text { Good participant } \\
\text { retention } \geq 60 \%\end{array}$ & $\begin{array}{l}1 \text { or } 2 \text { items taken from a } \\
\text { standardised measure of } \\
\text { a wider psychological } \\
\text { assessment }\end{array}$ & $\begin{array}{l}1 \text { or } 2 \text { items taken from a } \\
\text { standardised measure of a wider } \\
\text { psychological assessment to assess } \\
\text { either suicidal ideation or suicidal } \\
\text { behaviour; }\end{array}$ & Yes \\
\hline 2 & & $\begin{array}{l}\text { Accounts for additional } \\
\text { confounding variables } \\
\text { e.g. suicide history, } \\
\text { depression, other } \\
\text { psychological variables }\end{array}$ & & $\begin{array}{l}\text { Full measure or subscale } \\
\text { targeted to explore } \\
\text { loneliness }\end{array}$ & $\begin{array}{l}\text { Full measure or subscale targeted } \\
\text { to assess suicidal ideation or } \\
\text { suicidal behaviour; } \\
\text { Hospital records, death certificate } \\
\text { or coroner's report }\end{array}$ & \\
\hline
\end{tabular}


Table 2. Summary of studies included in review including sample demographics and characteristics, study methods, measures used and results

\begin{tabular}{|c|c|c|c|c|c|c|c|}
\hline \multirow{3}{*}{$\begin{array}{c}\text { Study } \\
\text { Country } \\
\text { Quality } \\
\text { Assessment } \\
\text { (QA) score } \\
\text { (Max 9) } \\
\text { In meta- } \\
\text { analysis } \\
\text { (Y/N) }\end{array}$} & \multirow{3}{*}{$\begin{array}{c}\text { Sample } \\
\text { demographics at } \\
\text { baseline } \\
\text { (n, \% female, age) }\end{array}$} & \multirow{3}{*}{$\begin{array}{l}\text { Type of } \\
\text { sample }\end{array}$} & \multirow{3}{*}{$\begin{array}{c}\text { Follow- } \\
\text { up } \\
\text { duration } \\
\text { (average) }\end{array}$} & \multicolumn{3}{|c|}{ Measures } & \multirow[t]{3}{*}{ Results } \\
\hline & & & & Loneliness & Suicide & Depression & \\
\hline & & & & & & & \\
\hline $\begin{array}{l}\text { Ayalon and } \\
\text { Shiovitz-Ezra } \\
\text { (2011) } \\
\text { Europe } \\
\text { QA score= } 6 \\
\text { Meta-analysis: } \\
\text { Yes }\end{array}$ & $\begin{array}{l}\text { Group 1: aged 50-65 } \\
\text { years }(n=6,294) \\
\text { Group 2: aged 66-75 } \\
\text { years ( } n=2,891) \\
\text { Group 3: aged >75 } \\
\text { years ( } n=1,503) \\
\text { (54.4\% female) }\end{array}$ & $\begin{array}{l}\text { Community } \\
\text { sample } \\
\text { Ethnicity: NA }\end{array}$ & $2-3$ years & $\begin{array}{l}\text { CES-D; ideation, } \\
1 \text { item (Radloff, } \\
1977 \text { ) }\end{array}$ & $\begin{array}{l}\text { Ideation: Euro-D; } \\
1 \text { item (Prince et } \\
\text { al., 1999) } \\
\text { Behaviour: None }\end{array}$ & $\begin{array}{l}\text { Euro-D (Prince et } \\
\text { al., 1999) }\end{array}$ & $\begin{array}{l}\text { Unadjusted: Loneliness was a } \\
\text { significant predictor of passive } \\
\text { death wishes in all three age } \\
\text { groups ( } p<0.001 \text { ) } \\
\text { Adjusted: Loneliness was a } \\
\text { significant predictor of passive } \\
\text { death wishes in Groups } 1 \text { and } 2 \\
\text { only ( }<<0.001 \text { ). Loneliness was no } \\
\text { longer a significant predictor of } \\
\text { later passive death wishes in } \\
\text { Group } 3 \text { once demographics } \\
\text { (gender, education and } \\
\text { geographic region) were } \\
\text { controlled }(p<0.001) .\end{array}$ \\
\hline $\begin{array}{l}\text { Bennardi et al. } \\
\text { (2019) } \\
\text { Spain } \\
\text { QA score= } 8 \\
\text { Meta-analysis: } \\
\text { yes }\end{array}$ & $\begin{array}{l}\text { Group 1: } n=1,206 \\
\text { (53.9\%; } 18-59 \text { years) } \\
\text { Group } 2:(n=1,186) \\
\text { (54.5\% female, age: } \\
60+\text { years) }\end{array}$ & $\begin{array}{l}\text { General } \\
\text { population } \\
\text { Ethnicity: NA }\end{array}$ & $\begin{array}{l}3.5( \pm 0.18) \\
\text { years }\end{array}$ & $\begin{array}{l}\text { UCLA (Russell, } \\
\text { Peplau and } \\
\text { Cutrona, 1980; } \\
\text { Spanish } \\
\text { translation) }\end{array}$ & $\begin{array}{l}\text { Ideation: WHO } \\
\text { CIDI- suicide } \\
\text { module } \\
\text { (Kessler and Üstün, } \\
\text { 2004) } \\
\text { Behaviour: Nonet† }\end{array}$ & $\begin{array}{l}\text { WHO CIDI - } \\
\text { WMH survey } \\
\text { version (Kessler } \\
\text { and Üstün, 2004) }\end{array}$ & $\begin{array}{l}\text { Unadjusted: Not available } \\
\text { Adjusted: Suicidal ideation } \\
\text { remained significantly predictive } \\
\text { of suicidal ideation at follow-up in } \\
\text { Group } 2 \text { only. }(p=0.009)\end{array}$ \\
\hline
\end{tabular}




\begin{tabular}{|c|c|c|c|c|c|c|c|}
\hline $\begin{array}{l}\text { Bonner \& Rich } \\
\text { (1988) } \\
\text { USA }\end{array}$ & $\begin{array}{l}\text { (54.3\% female; age: } \\
\text { NA) }\end{array}$ & $\begin{array}{l}\text { University } \\
\text { students }\end{array}$ & 6 weeks & $\begin{array}{l}\text { UCLA (Russell, } \\
\text { Peplau and } \\
\text { Cutrona, 1980) }\end{array}$ & $\begin{array}{l}\text { Ideation: SSI (Beck, } \\
\text { Kovacs \& } \\
\text { Weissman, 1979) }\end{array}$ & $\begin{array}{l}\text { Self-Rating } \\
\text { Depression Scale } \\
\text { (Zung, 1963) }\end{array}$ & $\begin{array}{l}\text { Unadjusted: Loneliness } \\
\text { significantly predicted suicidal } \\
\text { ideation at follow-up }(p<0.05)\end{array}$ \\
\hline $\begin{array}{l}\text { QA: } 4 \\
\text { Meta-analysis: } \\
\text { Yes }\end{array}$ & & Ethnicity: NA & & & Behaviour: None & & Adjusted: None \\
\hline $\begin{array}{l}\text { Fulginiti et al. } \\
\text { (2018) } \\
\text { USA } \\
\text { QA: } 7 \\
\text { Meta-analysis: } \\
\text { Yes }\end{array}$ & $\begin{array}{l}\mathrm{N}=995 \\
(59.9 \% \text { Female; age: } \\
11-18 \text { years })\end{array}$ & $\begin{array}{l}\begin{array}{l}\text { General } \\
\text { population }\end{array} \\
\text { Ethnicity: } \\
3 \% \text { White, } \\
27.6 \% \\
\text { Hispanic, } \\
\text { 19.5\% Black }\end{array}$ & 1.5 years & $\begin{array}{l}\text { LSDQ (Asher et } \\
\text { al. 1984) }\end{array}$ & $\begin{array}{l}\text { Ideation: CDI (1 } \\
\text { item) } \\
\text { Behaviour: None }\end{array}$ & CDI & $\begin{array}{l}\text { Unadjusted: loneliness did not } \\
\text { significantly predict suicidal } \\
\text { ideation at follow-up } \\
\text { Adjusted: None }\end{array}$ \\
\hline $\begin{array}{l}\text { Gallagher et } \\
\text { al. (2014; T1- } \\
\text { T3) }\end{array}$ & $\begin{array}{l}N=144 \\
(72 \% \text { female, Age: } \\
13.52 \pm 0.74)\end{array}$ & $\begin{array}{l}\text { Psychiatric } \\
\text { inpatients } \\
\text { either at risk to }\end{array}$ & 9 months & $\begin{array}{l}\text { LSDQ (Asher et } \\
\text { al. 1984) }\end{array}$ & $\begin{array}{l}\text { Ideation: SIQ } \\
\text { (Reynolds, 1985) }\end{array}$ & $\begin{array}{l}\text { DISC-IV (Shaffer } \\
\text { et al. 2000) }\end{array}$ & $\begin{array}{l}\text { Unadjusted: Loneliness } \\
\begin{array}{l}\text { significantly predicted suicidal } \\
\text { ideation } 9 \text { months later }(p<0.05)\end{array}\end{array}$ \\
\hline USA & & $\begin{array}{l}\text { themselves or } \\
\text { others }\end{array}$ & & & Behaviour: None & & Adjusted: None \\
\hline $\begin{array}{l}\text { QA: } 8 \\
\text { Meta-analysis: } \\
\text { Yes }\end{array}$ & & $\begin{array}{l}\text { 75\% White } \\
\text { 4\% Latino } \\
\text { 3\% African } \\
\text { American }\end{array}$ & & & & & \\
\hline $\begin{array}{l}\text { Gallagher et } \\
\text { al. (2014; T2- } \\
\text { T3) } \\
\text { USA }\end{array}$ & $\begin{array}{l}N=144 \\
\text { (72\% female, Age: } \\
13.52 \pm 0.74)\end{array}$ & $\begin{array}{l}\text { Psychiatric } \\
\text { inpatients } \\
\text { either at risk to } \\
\text { themselves or } \\
\text { others }\end{array}$ & 18 months & $\begin{array}{l}\text { LSDQ (Asher et } \\
\text { al. 1984) }\end{array}$ & $\begin{array}{l}\text { Ideation: SIQ } \\
\text { (Reynolds, 1985) } \\
\text { Behaviour: None }\end{array}$ & $\begin{array}{l}\text { DISC-IV (Shaffer } \\
\text { et al. 2000) }\end{array}$ & $\begin{array}{l}\text { Unadjusted: Loneliness did not } \\
\text { predict suicidal ideation } 18 \\
\text { months later. } \\
\text { Adjusted: None }\end{array}$ \\
\hline $\begin{array}{l}\text { QA: } 8 \\
\text { Meta-analysis: } \\
\text { Yes }\end{array}$ & & $\begin{array}{l}\text { 75\% White } \\
\text { 4\% Latino }\end{array}$ & & & & & \\
\hline
\end{tabular}




\begin{tabular}{|c|c|c|c|c|c|c|c|}
\hline & & $\begin{array}{l}\text { 3\% African } \\
\text { American }\end{array}$ & & & & & \\
\hline $\begin{array}{l}\text { Groholt et al. } \\
\text { (2006) } \\
\text { Norway } \\
\text { QA: } 4 \\
\text { Meta-analysis: } \\
\text { No }\end{array}$ & $\begin{array}{l}\mathrm{N}=92(90 \% \text { female, } \\
\text { Age: } 16.9 \pm 1.8)\end{array}$ & $\begin{array}{l}\text { Inpatients } \\
\text { admitted for } \\
\text { suicide attempt } \\
\text { Ethnicity: NA }\end{array}$ & 9 years & $\begin{array}{l}\text { UCLA- 5(Russell, } \\
\text { Peplau and } \\
\text { Cutrona, 1980) }\end{array}$ & $\begin{array}{l}\text { Ideation: None } \\
\text { Behaviour: self- } \\
\text { report suicide } \\
\text { attempt }\end{array}$ & BDI & $\begin{array}{l}\text { Unadjusted: loneliness did not } \\
\text { significantly predict suicide } \\
\text { attempt at follow-up. } \\
\text { Adjusted: None }\end{array}$ \\
\hline $\begin{array}{l}\text { Hom et al } \\
\text { (2019; T1-T3) } \\
\text { USA } \\
\text { QA: } 6 \\
\text { Meta-analysis: } \\
\text { Yes }\end{array}$ & $\begin{array}{l}\mathrm{N}=226 \text { ( } 89 \% \text { female; } \\
19.42 \text { years) }\end{array}$ & $\begin{array}{l}\begin{array}{l}\text { University } \\
\text { students }\end{array} \\
\text { 74\% White, } \\
\text { 6.6\% Black, } \\
\text { 13.7\% Latino } \\
\text { 3.5\% Asian }\end{array}$ & 1 month & $\begin{array}{l}\text { UCLA(Russell, } \\
\text { Peplau and } \\
\text { Cutrona, 1980) }\end{array}$ & $\begin{array}{l}\text { Ideation: DSI- } \\
\text { suicide subscale } \\
\text { (Joiner et al. 2002) } \\
\text { Behaviour: None }\end{array}$ & None & $\begin{array}{l}\text { Unadjusted: Loneliness } \\
\text { significantly predicted suicidal } \\
\text { ideation and follow-up }(p<0.01) \\
\text { Adjusted: None }\end{array}$ \\
\hline $\begin{array}{l}\text { Hom et al } \\
\text { (2019; T2-T3) } \\
\text { USA } \\
\text { QA: } 6 \\
\text { Meta-analysis: } \\
\text { Yes }\end{array}$ & $\begin{array}{l}\mathrm{N}=226 \text { ( } 89 \% \text { female; } \\
19.42 \text { years })\end{array}$ & $\begin{array}{l}\begin{array}{l}\text { University } \\
\text { students }\end{array} \\
\text { 74\% White, } \\
\text { 6.6\% Black, } \\
\text { 13.7\% Latino } \\
\text { 3.5\% Asian }\end{array}$ & 2 months & $\begin{array}{l}\text { UCLA(Russell, } \\
\text { Peplau and } \\
\text { Cutrona, 1980) }\end{array}$ & $\begin{array}{l}\text { Ideation: DSI- } \\
\text { suicide subscale } \\
\text { Behaviour: None }\end{array}$ & None & $\begin{array}{l}\text { Unadjusted: Loneliness } \\
\text { significantly predicted suicidal } \\
\text { ideation and follow-up }(p<0.01) \\
\text { Adjusted: None }\end{array}$ \\
\hline $\begin{array}{l}\text { Joiner and } \\
\text { Rudd } \\
\text { (1996) } \\
\text { USA } \\
\text { QA score= } 6 \\
\text { Meta-analysis: } \\
\text { Yes }\end{array}$ & $\begin{array}{l}\mathrm{N}=234 \\
(43.1 \% \text { female, } \\
19.9 \text { years }\end{array}$ & $\begin{array}{l}\text { University } \\
\text { students } \\
\text { Ethnicity: } \\
62 \% \text { Caucasian } \\
17 \% \text { Hispanic, } \\
21 \% \text { other }\end{array}$ & 10 weeks & $\begin{array}{l}\text { UCLA (Russell, } \\
\text { Peplau and } \\
\text { Cutrona, 1980) }\end{array}$ & $\begin{array}{l}\text { Ideation: DSI } \\
\text { Suicidality Subscale } \\
\text { (Metalsky, 1991) } \\
\text { Behaviour: None }\end{array}$ & $\begin{array}{l}\text { BDI (Beck et al., } \\
1988 \text { ) }\end{array}$ & $\begin{array}{l}\text { Unadjusted: Loneliness was a } \\
\text { significant predictor of suicidal } \\
\text { ideation }(r=0.3, p<0.01) \\
\text { Adjusted: Loneliness was no } \\
\text { longer a significant predictor of } \\
\text { suicidal ideation once depression } \\
\text { and hopelessness were controlled } \\
\text { for. }\end{array}$ \\
\hline
\end{tabular}




\begin{tabular}{|c|c|c|c|c|c|c|c|}
\hline $\begin{array}{l}\text { Joling and } \\
\text { O'Dwyer } \\
\text { (2018) } \\
\text { Netherlands } \\
\text { QA score= } 5 \\
\text { Meta-analysis: } \\
\text { Yes }\end{array}$ & $\begin{array}{l}\text { Group 1: } 9 \text { adults with } \\
\text { depression and } \\
\text { suicidal thoughts } \\
\text { Group 2: } 67 \text { adults } \\
\text { with depression and } \\
\text { no suicidal thoughts } \\
\text { Group 3: } 116 \text { with no } \\
\text { depression or suicidal } \\
\text { thoughts } \\
\text { (70.3\% female, } 69.5 \\
\pm 10.4 \text { years) }\end{array}$ & $\begin{array}{l}\text { Live-in carers } \\
\text { (adult } \\
\text { community } \\
\text { sample) } \\
\text { Ethnicity NA }\end{array}$ & 2 years & $\begin{array}{l}\text { De Jong Gierveld } \\
\text { loneliness scale } \\
\text { (de Jong- } \\
\text { Gierveld and } \\
\text { Kamphuls, 1985) }\end{array}$ & $\begin{array}{l}\text { Ideation: MINI, } 1 \\
\text { item (Sheehan et } \\
\text { al., 1998) } \\
\text { Behaviour: None }\end{array}$ & $\begin{array}{l}\text { CES-D (Radloff, } \\
\text { 1977) }\end{array}$ & $\begin{array}{l}\text { Unadjusted: Those who reported } \\
\text { suicidal ideation (Group } 1 \text { ) } \\
\text { reported the highest loneliness } \\
\text { scores at follow-up, followed by } \\
\text { Group } 2 \text { then } 3(p<0.01) \\
\text { Adjusted: None }\end{array}$ \\
\hline $\begin{array}{l}\text { Junker, } \\
\text { Bjorngaard, } \\
\text { and Bjerkeset } \\
\text { (2017) } \\
\text { Norway } \\
\text { QA score= 5 } \\
\text { Meta-analysis: } \\
\text { No }\end{array}$ & $\begin{array}{l}\mathrm{N}=8,965 \text { no history } \\
\text { of hospitalised self- } \\
\text { harm } \\
\text { ( } 49.7 \% \text { Female; } \\
16 \pm 1.08 \text { years at } \\
\text { follow-up) }\end{array}$ & $\begin{array}{l}\text { Adolescent } \\
\text { school sample } \\
\text { Ethnicity NA }\end{array}$ & 11.9 years & $\begin{array}{l}1 \text { item from } \\
\text { Young-HUNT } 1\end{array}$ & $\begin{array}{l}\text { Ideation: None } \\
\text { Behaviour: } \\
\text { Hospital records }\end{array}$ & $\begin{array}{l}\text { SCL-5 (Strand et } \\
\text { al., 2003) }\end{array}$ & $\begin{array}{l}\text { Unadjusted: None } \\
\text { Adjusted: Controlling for baseline } \\
\text { demographics, those who } \\
\text { reported a higher level of } \\
\text { loneliness at baseline were more } \\
\text { likely to attend hospital for self- } \\
\text { harm than those who reported a } \\
\text { lower level of loneliness. }\end{array}$ \\
\hline $\begin{array}{l}\text { Kleiman et al. } \\
\text { (2017, } \\
\text { Study 1) } \\
\text { Worldwide } \\
\text { QA score= } 2 \\
\text { Meta-analysis: } \\
\text { No }\end{array}$ & $\begin{array}{l}\mathrm{N}=54 \text { Attempted } \\
\text { suicide within the past } \\
\text { year ( } 79.6 \% \text { female, } \\
23.24 \pm 5.26 \text { years) }\end{array}$ & $\begin{array}{l}\text { Adult } \\
\text { community } \\
\text { sample }\end{array}$ & $\begin{array}{l}21.3 \pm 11.7 \\
\text { days }\end{array}$ & $\begin{array}{l}\text { EMA one-word } \\
\text { affect label }\end{array}$ & $\begin{array}{l}\text { Ideation: EMA one- } \\
\text { word affect label, } 3 \\
\text { items } \\
\text { Behaviour: None }\end{array}$ & None & $\begin{array}{l}\text { Unadjusted: Baseline loneliness } \\
\text { did not predict suicidal ideation at } \\
\text { follow-up. } \\
\text { Adjusted: Controlling for baseline } \\
\text { suicide ideation, loneliness did not } \\
\text { predict suicide ideation at follow- } \\
\text { up. }\end{array}$ \\
\hline $\begin{array}{l}\text { Kleiman et al. } \\
\text { (2017, } \\
\text { Study 2) }\end{array}$ & $\begin{array}{l}\mathrm{N}=36 \text { Severe suicide } \\
\text { ideation or recent } \\
\text { suicide attempt. }\end{array}$ & $\begin{array}{l}\text { Adult inpatient } \\
\text { sample }\end{array}$ & $\begin{array}{l}10.32 \pm \\
6.45 \text { days }\end{array}$ & $\begin{array}{l}\text { One-word EMA } \\
\text { affect } \\
\text { label }\end{array}$ & $\begin{array}{l}\text { Ideation: EMA one- } \\
\text { word affect label, } 3 \\
\text { items }\end{array}$ & None & $\begin{array}{l}\text { Unadjusted: Baseline loneliness } \\
\text { did not predict suicidal ideation at } \\
\text { follow-up. }\end{array}$ \\
\hline
\end{tabular}




\begin{tabular}{|c|c|c|c|c|c|c|c|}
\hline $\begin{array}{l}\text { USA } \\
\text { QA score= } 2 \\
\text { Meta-analysis: } \\
\text { No }\end{array}$ & $\begin{array}{l}\text { (44.1\% female, } 47.74 \\
\pm 13.06 \text { years) }\end{array}$ & $\begin{array}{l}\text { Ethnicity: } \\
82 \% \text { European } \\
\text { decent, } 5.9 \% \\
\text { Hispanic }\end{array}$ & & & Behaviour: None & & $\begin{array}{l}\text { Adjusted: Controlling for baseline } \\
\text { suicide ideation, loneliness did not } \\
\text { account for any variability in } \\
\text { suicide ideation at follow-up. }\end{array}$ \\
\hline $\begin{array}{l}\text { Lasgaard et al. } \\
\text { (2011) } \\
\text { Denmark } \\
\text { QA score= } 7 \\
\text { Meta-analysis: } \\
\text { Yes }\end{array}$ & $\begin{array}{l}N=541 * \\
(60 \% \text { female; } 17.11 \pm \\
1.12 \text { years })\end{array}$ & $\begin{array}{l}\text { Adolescent } \\
\text { High School } \\
\text { sample } \\
\text { Ethnicity NA }\end{array}$ & 1 year & $\begin{array}{l}\text { UCLA (Russell, } \\
\text { 1996) }\end{array}$ & $\begin{array}{l}\text { Ideation: SPS } \\
\text { Suicide Ideation } \\
\text { subscale (Cull and } \\
\text { Gill, 1989) } \\
\text { Behaviour: None }\end{array}$ & $\begin{array}{l}\text { BDI-Y; Danish } \\
\text { version (Thastum } \\
\text { et al., 2009) }\end{array}$ & $\begin{array}{l}\text { Unadjusted: Loneliness at baseline } \\
\text { significantly predicted suicide } \\
\text { ideation at follow-up. } \\
\text { Adjusted: When depression was } \\
\text { controlled for, loneliness was no } \\
\text { longer a predictor of later suicidal } \\
\text { ideation. }\end{array}$ \\
\hline $\begin{array}{l}\text { McGraw et al. } \\
\text { (2008) } \\
\text { Australia } \\
\text { QA score= } 2 \\
\text { Meta-analysis: } \\
\text { No }\end{array}$ & $\begin{array}{l}204^{*} \\
(59.8 \% \text { female; } 17.4 \pm \\
0.6 \text { years) }\end{array}$ & $\begin{array}{l}\text { Child } \\
\text { community } \\
\text { sample } \\
\text { Ethnicity: } \\
82 \% \text { Australian }\end{array}$ & 1 year & $\begin{array}{l}\text { UCLA-R (Russell, } \\
\text { Peplau and } \\
\text { Cutrona, 1980) }\end{array}$ & $\begin{array}{l}\text { Ideation: } 1 \text { item; 'I } \\
\text { thought about } \\
\text { hurting myself' } \\
\text { Behaviour: None }\end{array}$ & $\begin{array}{l}\text { DASS-21 } \\
\text { (Lovibond and } \\
\text { Lovibond, 1995) }\end{array}$ & $\begin{array}{l}\text { Unadjusted: Those who reported } \\
\text { self-harm ideation at follow-up } \\
\text { had reported lower peer } \\
\text { connectedness (therefore higher } \\
\text { loneliness) at baseline. } \\
\text { Adjusted: None }\end{array}$ \\
\hline $\begin{array}{l}\text { Nickel et al. } \\
\text { (2006) } \\
\text { Germany, } \\
\text { Austria and } \\
\text { Poland } \\
\text { QA score= } 3 \\
\text { Meta-analysis: } \\
\text { Yes }\end{array}$ & $\begin{array}{l}\text { Group 1: } \mathrm{N}=388 \\
\text { Patients with bulimia } \\
\text { (purging type), no } \\
\text { depression } \\
\text { Group 2: } \mathrm{N}=425 \\
\text { Patients with } \\
\text { depression, no eating } \\
\text { disorder } \\
\text { (female only; } 28 \pm 4 \\
\text { years. }\end{array}$ & $\begin{array}{l}\text { Adult mixed } \\
\text { samples } \\
\text { (inpatient, } \\
\text { outpatient and } \\
\text { community) } \\
\text { Ethnicity NA }\end{array}$ & 1 year & $\begin{array}{l}\text { QoL, } 1 \text { item } \\
\text { (Averbeck et al., } \\
\text { 1997) }\end{array}$ & $\begin{array}{l}\text { Ideation: None } \\
\text { Behaviour: } 1 \text { item; } \\
\text { attempting suicide } \\
\text { in the last } 12 \\
\text { months }\end{array}$ & None & $\begin{array}{l}\text { Unadjusted: Loneliness at baseline } \\
\text { was identified as a significant } \\
\text { predictor of suicide attempts in } \\
\text { the } 12 \text {-months post-baseline in } \\
\text { the Bulimia Nervosa group but not } \\
\text { the Major Depression group. } \\
\text { Adjusted: None }\end{array}$ \\
\hline
\end{tabular}




\begin{tabular}{|c|c|c|c|c|c|c|c|}
\hline $\begin{array}{l}\text { Pietrzak et al. } \\
\text { (2017) } \\
\text { USA } \\
\text { QA score }=7 \\
\text { Meta-analysis: } \\
\text { Yes }\end{array}$ & $\begin{array}{l}\mathrm{N}=2,093 \\
\text { no suicidal ideation } \\
\text { ( } 8 \% \text { female, } 62.4 \pm \\
13.8 \text { years) }\end{array}$ & $\begin{array}{l}\text { Adult veteran } \\
\text { sample } \\
\text { Ethnicity: } \\
78.5 \% \\
\text { Caucasian }\end{array}$ & 4 years & $\begin{array}{l}\text { Short Loneliness } \\
\text { Scale }\end{array}$ & $\begin{array}{l}\text { Ideation: PHQ-9, 1- } \\
\text { item (Spitzer et al., } \\
\text { 1999) } \\
\text { Behaviour: None }\end{array}$ & None & $\begin{array}{l}\text { Unadjusted: Baseline loneliness } \\
\text { was associated with increased } \\
\text { incident of suicidal ideation at a } \\
\text { later time point. } \\
\text { Adjusted: None }\end{array}$ \\
\hline $\begin{array}{l}\text { Salzinger et al. } \\
\text { (2007) } \\
\text { USA } \\
\text { QA score= } 5 \\
\text { Meta-analysis: } \\
\text { Yes }\end{array}$ & $\begin{array}{l}\text { Group 1: } N=100 \text { urban } \\
\text { school children } \\
\text { registered on the NYC } \\
\text { Maltreatment } \\
\text { Register. } \\
\text { Group 2: } N=100 \\
\text { healthy, matched } \\
\text { controls. ( } 35 \% \text { female, } \\
10.5 \pm 0.9 \text { years old) }\end{array}$ & 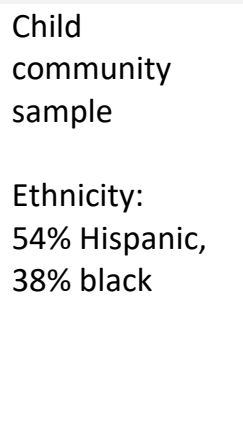 & $\begin{array}{l}6 \pm 0.6 \\
\text { years }\end{array}$ & $\begin{array}{l}\text { LSDQ (Asher et } \\
\text { al. 1984) }\end{array}$ & $\begin{array}{l}\text { Ideation: YRBS, 4- } \\
\text { items. } \\
\text { Behaviour: YRBS. } 2 \\
\text { items (Garrison et } \\
\text { al., 1993) }\end{array}$ & None & $\begin{array}{l}\text { Unadjusted: Loneliness did not } \\
\text { predict suicide ideation or } \\
\text { behaviour at follow-up. } \\
\text { Adjusted: None }\end{array}$ \\
\hline $\begin{array}{l}\text { Schinka et al. } \\
\text { (2013; SI T1- } \\
\text { T3)† } \\
\text { USA } \\
\text { QA score= } 5 \\
\text { Meta-analysis: } \\
\text { Yes }\end{array}$ & $\begin{array}{l}\mathrm{N}=832(51.1 \% \text { female, } \\
9 \text { years })\end{array}$ & $\begin{array}{l}\text { Child school } \\
\text { sample } \\
\text { 79\% Caucasian, } \\
\text { 10.5\% African } \\
\text { American }\end{array}$ & 4 years: & $\begin{array}{l}\text { LSDQ (Asher et } \\
\text { al., 1984) }\end{array}$ & $\begin{array}{l}\text { Ideation: CBCL 1- } \\
\text { item self-report } \\
\text { (Achenbach, 1992); } \\
\text { YSR } 1 \text { item, parent } \\
\text { report from YSR } \\
\text { (Achenbach, 1991) } \\
\text { Behaviour: None }\end{array}$ & $\begin{array}{l}\text { CBCL; subscale } \\
\text { (Achenbach, } \\
\text { 1991). }\end{array}$ & $\begin{array}{l}\text { Unadjusted: Loneliness did not } \\
\text { predict suicidal ideation at follow- } \\
\text { up. } \\
\text { Adjusted: None }\end{array}$ \\
\hline $\begin{array}{l}\text { Schinka et al. } \\
\text { (2013; SB T1- } \\
\text { T3)† } \\
\text { USA } \\
\text { QA score= } 5 \\
\text { Meta-analysis: } \\
\text { Yes }\end{array}$ & $\begin{array}{l}\mathrm{N}=832(51.1 \% \text { female, } \\
9 \text { years })\end{array}$ & $\begin{array}{l}\text { Child school } \\
\text { sample } \\
\text { 79\% Caucasian, } \\
\text { 10.5\% African } \\
\text { American }\end{array}$ & 4 years & $\begin{array}{l}\text { LSDQ (Asher et } \\
\text { al., 1984) }\end{array}$ & $\begin{array}{l}\text { Ideation: None } \\
\text { Behaviour: CBCL 1- } \\
\text { item self-report } \\
\text { (Achenbach, 1992); } \\
\text { YSR } 1 \text { item, parent- } \\
\text { report from YSR } \\
\text { (Achenbach, 1991) }\end{array}$ & $\begin{array}{l}\text { CBCL; subscale } \\
\text { (Achenbach, } \\
\text { 1991). }\end{array}$ & $\begin{array}{l}\text { Unadjusted: Loneliness did not } \\
\text { predict suicide attempt at follow- } \\
\text { up. } \\
\text { Adjusted: None }\end{array}$ \\
\hline
\end{tabular}




\begin{tabular}{|c|c|c|c|c|c|c|c|}
\hline $\begin{array}{l}\text { Schinka et al. } \\
(2013, \text { T2-T3) } \\
\text { USA } \\
\text { QA score= } 5 \\
\text { Meta-analysis: } \\
\text { Yes }\end{array}$ & $\begin{array}{l}\mathrm{N}=832(51.1 \% \text { female, } \\
11 \text { years })\end{array}$ & $\begin{array}{l}\text { Child school } \\
\text { sample } \\
\text { 79\% Caucasian, } \\
\text { 10.5\% African } \\
\text { American }\end{array}$ & 6 years & $\begin{array}{l}\text { LSDQ (Asher et } \\
\text { al., 1984) }\end{array}$ & $\begin{array}{l}\text { Ideation CBCL 1- } \\
\text { item self-report } \\
\text { (Achenbach, 1992); } \\
\text { YSR } 1 \text { item, parent } \\
\text { report from YSR } \\
\text { (Achenbach, 1991) } \\
\text { Behaviour: None }\end{array}$ & $\begin{array}{l}\text { CBCL; subscale } \\
\text { (Achenbach, } \\
\text { 1991). }\end{array}$ & $\begin{array}{l}\text { Unadjusted: Loneliness did not } \\
\text { predict suicidal ideation at follow- } \\
\text { up. } \\
\text { Adjusted: None }\end{array}$ \\
\hline $\begin{array}{l}\text { Schinka et al. } \\
(2013, T 2-T 3) \dagger \\
\text { USA } \\
\text { QA score= } 5 \\
\text { Meta-analysis: } \\
\text { Yes }\end{array}$ & $\begin{array}{l}\mathrm{N}=832(51.1 \% \text { female, } \\
11 \text { years })\end{array}$ & $\begin{array}{l}\text { Child school } \\
\text { sample } \\
\text { 79\% Caucasian, } \\
\text { 10.5\% African } \\
\text { American }\end{array}$ & 6 years & $\begin{array}{l}\text { LSDQ (Asher et } \\
\text { al., 1984) }\end{array}$ & $\begin{array}{l}\text { Ideation None } \\
\text { Behaviour; CBCL 1- } \\
\text { item self-report } \\
\text { (Achenbach, 1992); } \\
\text { YSR } 1 \text { item, parent- } \\
\text { report from YSR } \\
\text { (Achenbach, 1991) }\end{array}$ & $\begin{array}{l}\text { CBCL; subscale } \\
\text { (Achenbach, } \\
\text { 1991). }\end{array}$ & $\begin{array}{l}\text { Unadjusted: Loneliness did not } \\
\text { predict suicidal attempt at follow- } \\
\text { up. } \\
\text { Adjusted: None }\end{array}$ \\
\hline $\begin{array}{l}\text { Stein, Itzhaky } \\
\text { and Levi-Belz } \\
\text { (2017) } \\
\text { Israel } \\
\text { QA score= } 6 \\
\text { Meta-analysis: } \\
\text { Yes }\end{array}$ & $\begin{array}{l}\text { Group 1: } \mathrm{N}=163, \mathrm{Ex}- \\
\text { prisoner of Kippur } \\
\text { War (Male only, } 53.4 \\
\pm 4.4 \text { years) } \\
\text { Group 2: } \mathrm{N}=185 \\
\text { matched non- captive } \\
\text { veterans (Male } \\
\text { only, } 53.4 \pm 4.4 \text { years } \\
\text { approx.) }\end{array}$ & $\begin{array}{l}\text { Adult ex- } \\
\text { military } \\
\text { 79\% Caucasian, } \\
\text { 10.5\% African } \\
\text { American }\end{array}$ & 12 years & $\begin{array}{l}\text { UCLA (Russell } \\
1996 \text { ) }\end{array}$ & $\begin{array}{l}\text { Ideation: SCL-90, } 2 \\
\text { items (Derogatis } \\
\text { and Cleary, 1977) } \\
\text { Behaviour: None }\end{array}$ & None & $\begin{array}{l}\text { Unadjusted: Loneliness at baseline } \\
\text { was not a significant independent } \\
\text { predictor of suicide ideation at } \\
\text { follow-up. } \\
\text { Adjusted: None }\end{array}$ \\
\hline
\end{tabular}




\begin{tabular}{|c|c|c|c|c|c|c|c|}
\hline $\begin{array}{l}\text { Stolz et al. } \\
\text { (2016) } \\
\text { Europe } \\
\text { QA score= } 4 \\
\text { Meta-analysis: } \\
\text { Yes }\end{array}$ & $\begin{array}{l}N=6,791 \\
(57.6 \% \text { female, } 80.5 \pm \\
4.5 \text { years) }\end{array}$ & 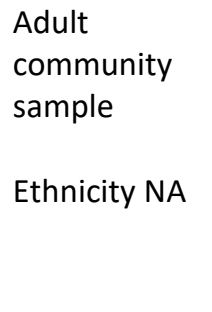 & 2 years & $\begin{array}{l}1 \text { item, 2-point } \\
\text { categorical } \\
\text { question; 'Do } \\
\text { you often feel } \\
\text { lonely?' }\end{array}$ & $\begin{array}{l}\text { Ideation: EURO-D, } \\
1 \text { item from (Prince } \\
\text { et al., 1999) } \\
\text { Behaviour: None }\end{array}$ & None & $\begin{array}{l}\text { Unadjusted: Those who reported } \\
\text { often feeling lonely, or who } \\
\text { reported an increase in feelings of } \\
\text { loneliness were at increased risk } \\
\text { of developing passive suicide } \\
\text { ideation ( } p<0.001) \text {. } \\
\text { Adjusted: None }\end{array}$ \\
\hline $\begin{array}{l}\text { Trakhtenbrot } \\
\text { et al. } \\
\text { (2016) } \\
\text { Israel } \\
\text { QA score }=7 \\
\text { Meta-analysis: } \\
\text { No }\end{array}$ & $\begin{array}{l}\text { Group1: } \mathrm{N}=53 \text {, history } \\
\text { of medically serious } \\
\text { suicide attempt } \\
\text { (MSSA; } 41.5 \% \text { female, } \\
37.6 \pm 12.25 \text { years) } \\
\text { Group } 2 \text { : } \mathrm{N}=64 \text { history } \\
\text { of medically non- } \\
\text { serious suicide } \\
\text { attempt (MNSSA; } \\
39.1 \% \text { female, } 37.74 \pm \\
13.05 \text { years) } \\
\text { Group } 3: \mathrm{N}=36 \\
\text { Psychiatric inpatients } \\
\text { (153 participants } \\
\text { total; } 40.27 \% \text { female, } \\
40.27 \pm 13.26 \text { years) }\end{array}$ & $\begin{array}{l}\text { Adult } \\
\text { psychiatric } \\
\text { inpatient } \\
\text { sample } \\
\text { Ethnicity NA }\end{array}$ & $\begin{array}{l}5.6 \pm 2.53 \\
\text { years }\end{array}$ & $\begin{array}{l}\text { UCLA (Russell } \\
\text { 1996) }\end{array}$ & $\begin{array}{l}\text { Ideation: None } \\
\text { Behaviour: } \\
\text { Hospital records }\end{array}$ & BDI (Beck, 1978) & $\begin{array}{l}\text { Unadjusted: None } \\
\text { Adjusted: After controlling for } \\
\text { demographic characteristics and } \\
\text { mental pain domains, baseline } \\
\text { loneliness was not a significant } \\
\text { predictor of suicide behaviour at } \\
\text { follow-up. }\end{array}$ \\
\hline $\begin{array}{l}\text { Wichstrøm } \\
(2009) \\
\text { Norway } \\
\text { QA score= } 4 \\
\text { Meta-analysis: } \\
\text { Yes }\end{array}$ & $\begin{array}{l}N=3,906 \\
(56 \% \text { female, } 16.5 \pm \\
1.9 \text { years })\end{array}$ & 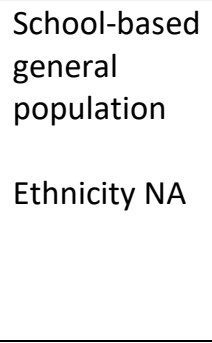 & 5 years & $\begin{array}{l}\text { UCLA; } 5 \text {-items } \\
\text { (Russel et al. } \\
\text { 1980) }\end{array}$ & $\begin{array}{l}\text { Ideation: None } \\
\text { Behaviour: 2- } \\
\text { items; Taken an } \\
\text { overdose of pills or } \\
\text { otherwise tried to } \\
\text { harm yourself on } \\
\text { purpose? }\end{array}$ & $\begin{array}{l}\text { Depressive } \\
\text { Mood Inventory } \\
\text { (Kandel and } \\
\text { Davies, 1982) }\end{array}$ & $\begin{array}{l}\text { Unadjusted: Baseline loneliness } \\
\text { scores were significantly different } \\
\text { between those reporting no self- } \\
\text { injury, NSSI and suicide attempts } \\
\text { at follow-up. } \\
\text { Adjusted: Multinomical logistic } \\
\text { regression found loneliness to be a } \\
\text { significant predictor of self-injury }\end{array}$ \\
\hline
\end{tabular}


Have you ever

tried to kill

yourself?' at follow-up after controlling for demographic characterises and baseline variables

$\mathrm{BDI}=$ Beck Depression Inventory; BDI-Y= Beck Depression Inventory for Youth; $\mathrm{CBCL}=$ Child Behaviour Checklist; $\mathrm{CDI}=\mathrm{Childrens} \mathrm{Depression} \mathrm{Inventory} \mathrm{CES-D=Centre} \mathrm{for}$ Epidemiologic Studies Depression Scale; DASS-21= Depression, Anxiety and Stress Scale; DISC-IV= Diagnostic Interview Schedule for Children; DSI= Depressive Symptom Inventory; EMA= Ecological Momentary Assessment; EURO-D= Euro- depression scale; LSDQ= Loneliness and Social Dissatisfaction Questionnaire; MIN= Mini-International Neuropsychological Interview; PHQ-9= Patient Health Questionnaire-9; QoL= Quality of Life Questionnaire; SB= Suicide Behaviour; SI= Suicide ideation; SLC-5= Hopkins Symptom Checklist; SCL-90= Symptom Checklist-90; SIQ= Suicide Ideation Questionnaire; SPS= Suicide Probability Scale; SSI= Scale for Suicidal Ideation; T=Timepoint; UCLA= UCLA Loneliness Scale; UCLA-R = UCLA- Revised Scale; WHO CIDI= World Health Organisation Composite International Diagnostic Interview 3.0; YRBS= Youth Risk Behavior Survey; YSR= Youth Self-Report.

* Sample size and demographic data recorded at follow-up. + Studies which share the same sample population from the NICHD study. ++ Suicide behaviour data was excluded due to insufficient data, see appendix 1 for details. 
Figure 2. Forest plot of overall effect sizes from whole participant group

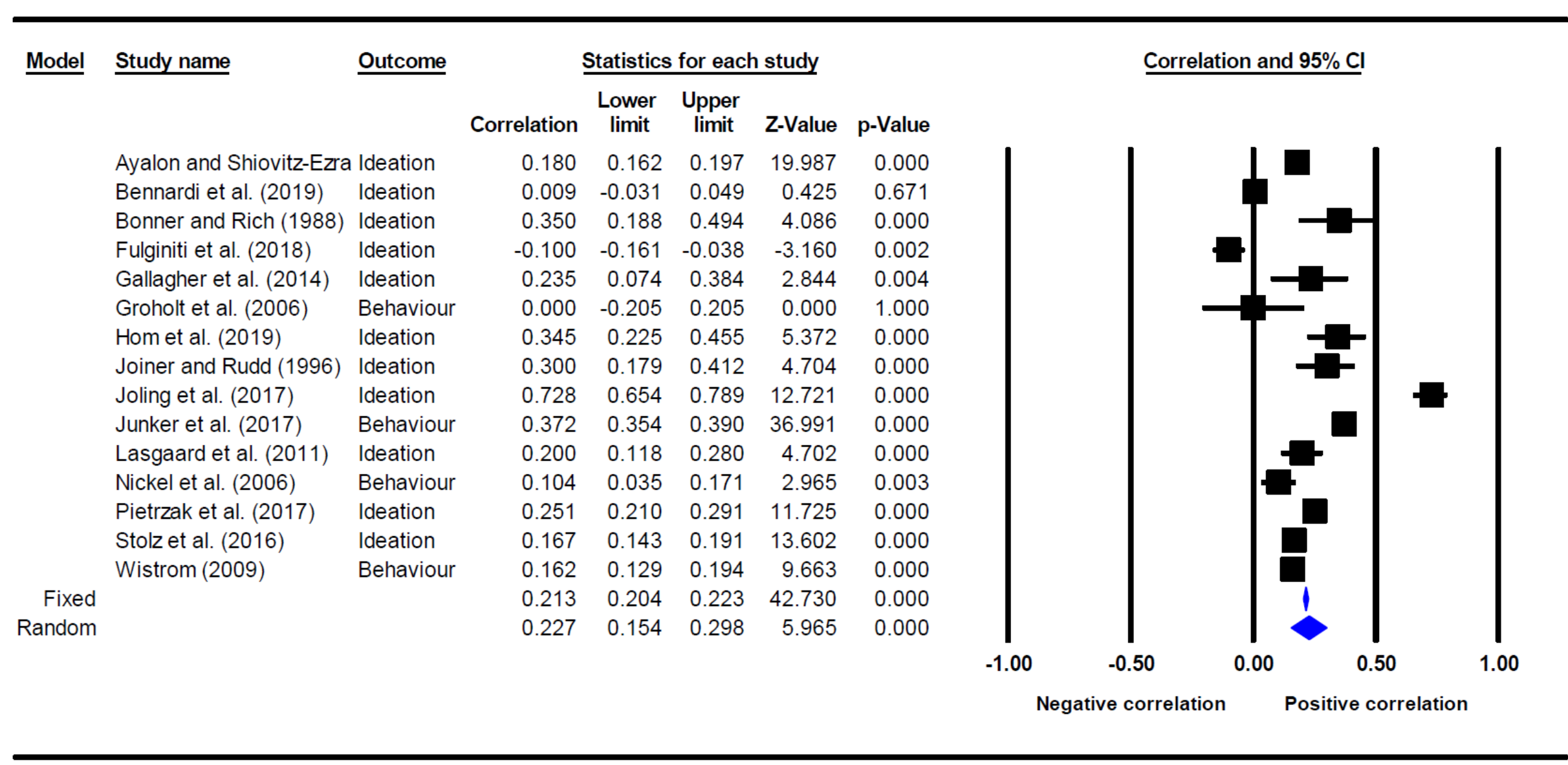


Figure 3. Funnel plot illustrating publication bias following a random effects model of overall effect sizes included in meta-analysis ( $n=17)$

\section{Funnel Plot of Standard Error by Fisher's Z}

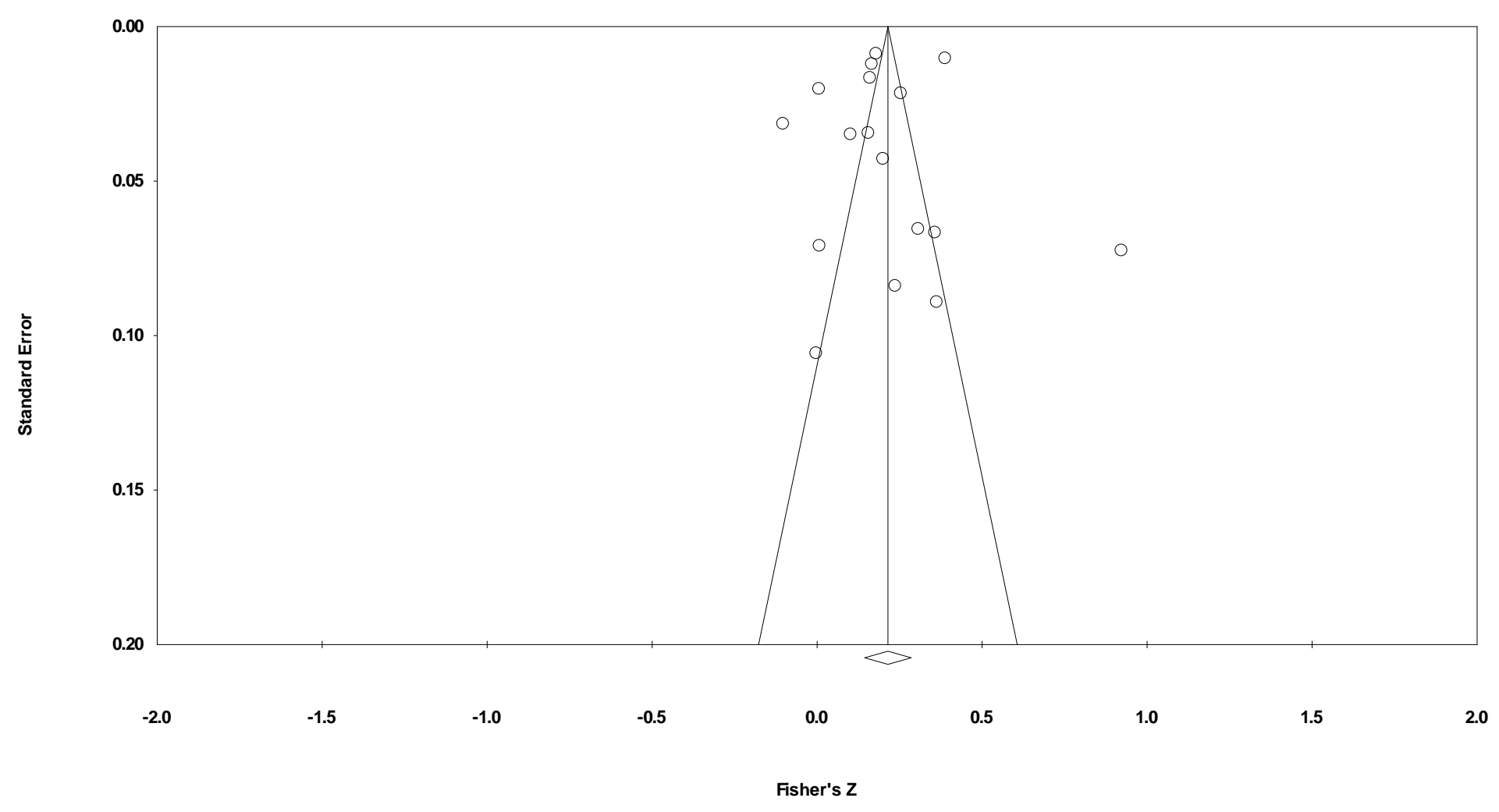

The effect sizes appear to be symmetrically distributed on either side of the mean effect size which is illustrated by the vertical line. As all studies ( $n=17)$ are in the top-half of the funnel, this indicates that most studies used a large sample size. 
Figure 4. Age as a continuous moderator between loneliness and later SIB.

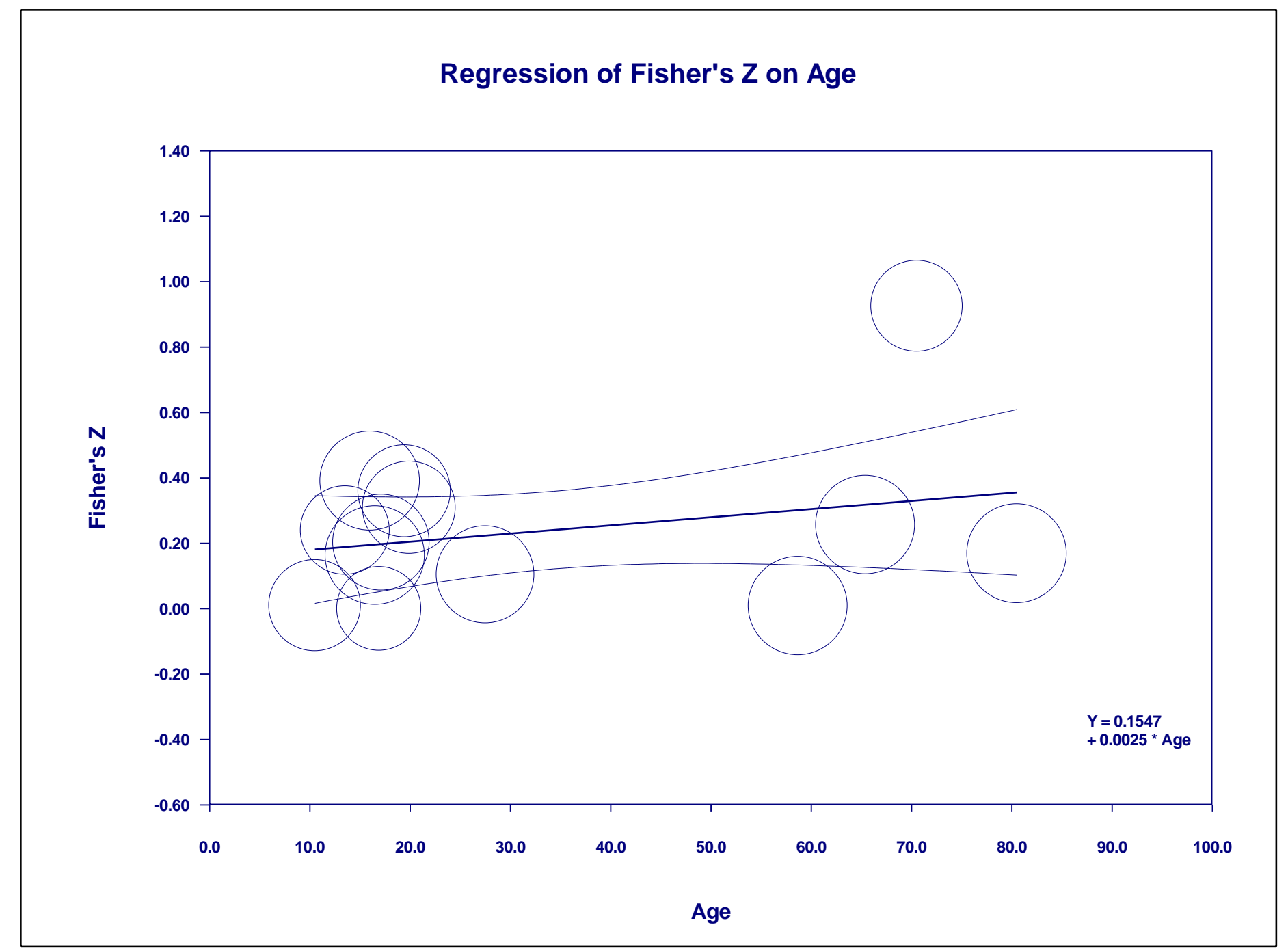

Combined effect sizes for all studies with multiple outputs (i.e. Gallagher et al., 2014, Hom et al., 2019; Salzinger et al., 2007; Schinka et al., 2013) 
Figure 5. Forest plot between gender

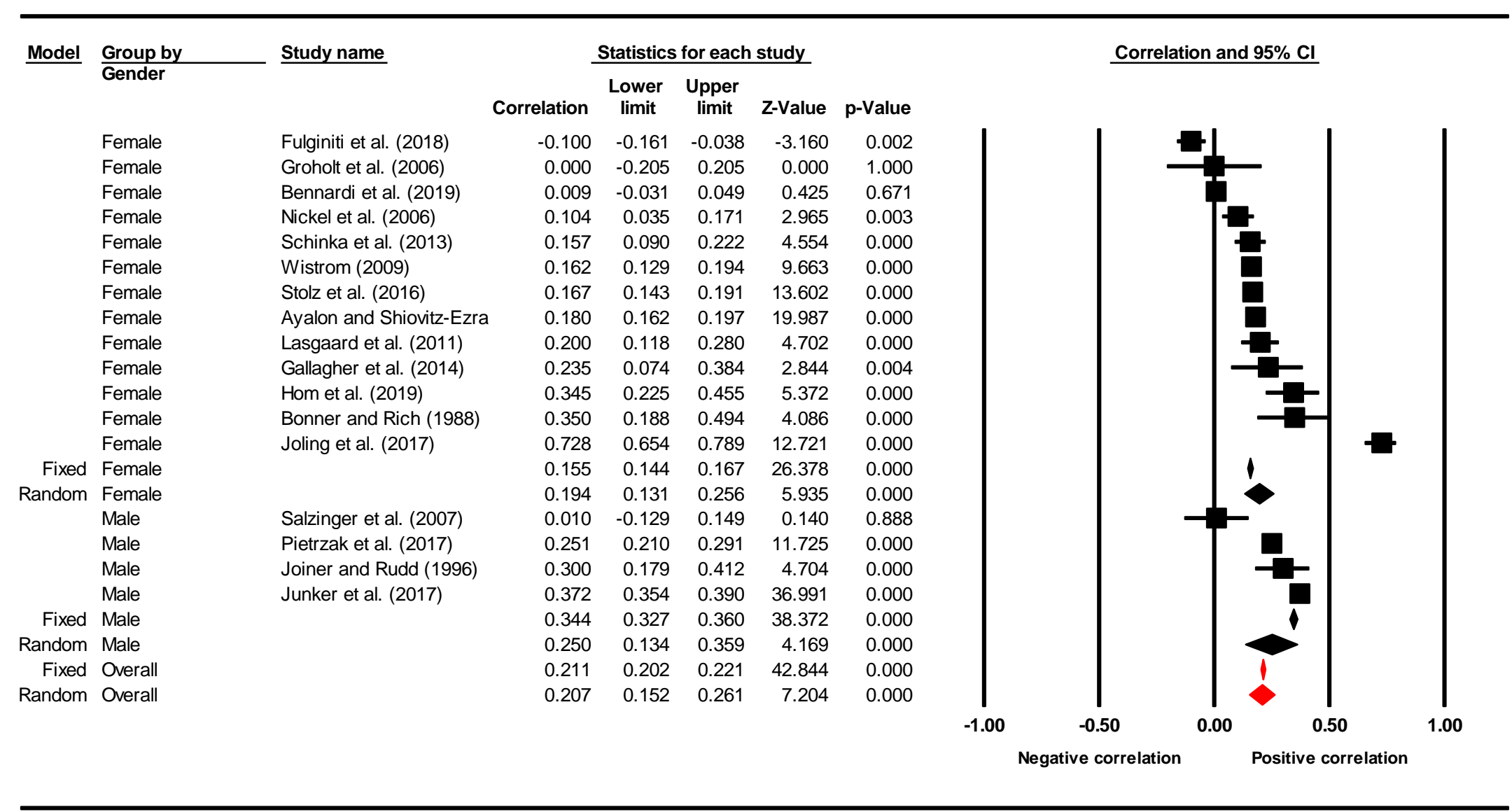

Meta Analysis 
Table 3. Controlled variables for adjusted univariate analysis between loneliness and SIB.

\begin{tabular}{ll}
\hline \hline Study & Variables controlled \\
\hline $\begin{array}{l}\text { Ayalon and Shiovitz- } \\
\text { Ezra } \\
\text { (2011) }\end{array}$ & $\begin{array}{l}\text { Age gender, education, geographic region. } \\
\text { Physical health: chronic conditions, activities of daily living, instrumental activities } \\
\text { of daily living, health indicators: medical status } \\
\text { Mental health: depressive symptoms, hope } \\
\text { Social variables: marital status, parent alive, number of living siblings, number of } \\
\text { living children, living arrangement, activity level }\end{array}$ \\
$\begin{array}{l}\text { Bennardi et al. } \\
\text { (2019) }\end{array}$ & $\begin{array}{l}\text { Age, gender, years of education, baseline suicide ideation, heavy alcohol use, } \\
\text { baseline depression and health status. }\end{array}$ \\
$\begin{array}{l}\text { Joiner and Rudd } \\
\text { (1996) }\end{array}$ & Hopelessness \\
$\begin{array}{l}\text { Junker, Bjorngaard } \\
\text { and Bjerkeset } \\
\text { (2017) }\end{array}$ & $\begin{array}{l}\text { Age, gender, cohabitation situation, socio-economic status/ parental education } \\
\text { level at baseline }\end{array}$ \\
$\begin{array}{l}\text { Kleiman et al. } \\
\text { (2017, study 1) }\end{array}$ & Baseline suicidal ideation \\
$\begin{array}{l}\text { Kleiman et al. } \\
\text { (2017, study 2) }\end{array}$ & Baseline suicidal ideation \\
$\begin{array}{l}\text { Lasgaard, Goossens } \\
\text { and Elklit (2011) }\end{array}$ & $\begin{array}{l}\text { Depression } \\
\text { Trakhtenbrot et al. } \\
\text { (2016) }\end{array}$ \\
$\begin{array}{l}\text { Wichstrom } \\
\text { (2009) }\end{array}$ & $\begin{array}{l}\text { Age, gender } \\
\text { Mental pain domain: mental pain, depression, hopelessness }\end{array}$ \\
& $\begin{array}{l}\text { Demographic characteristics: age, gender } \\
\text { Baseline variables: self-injury }\end{array}$ \\
&
\end{tabular}


Appendix 1. Clarification of included studies

1. Kleiman et al. (2017) contained two studies with separate methods and participants so was split for the purpose of this review and are referred to as; Kleiman et al., (2017, study 1) and Kleiman et al. (2017, study 2).

2. Nickel et al. (2006) refers to their outcome variable as 'suicide attempts', however the authors of this review believed the criteria set by Nickel et al. (2006) was more reflective of suicide behaviour in general and is therefore categorised as such in this review.

3. Pietrzak et al. (2017) is a letter to the editor instead of a peer-reviewed article. As this paper met all study criteria and was still published in a peer-reviewed journal, it was agreed between the review authors that this study would be included.

4. Bennardi et al. (2019) did not provide results on suicidal behaviour due to lack of data, therefore only the results regarding suicidal ideation are considered for this review.

5. Gallagher et al. (2014), Hom et al. (2019) and Schinka et al. (2013) all reported two effect sizes between loneliness and later SIB, where loneliness was measured at different timepoints (referred to as T1 and T2) and SIB measured at a single later timepoint (T3). These results are therefore referred to based on their timepoint of loneliness and SIB assessments and where appropriate, their outcome measure (ideation vs. behaviour). See Table 2 for further details.

Appendix 2. Reasons for studies not included in the meta-analysis

- Two authors (Stein et al., 2017; Trakhtenbrot et al., 2016) did not respond to review authors request for further information.

- One author (McGraw et al., 2008) no longer had access to the raw data to required to be included in the meta-analysis.

- Two studies (Kleiman et al. 2017, study 1 and 2) used Ecological Monitory Assessment (EMA) which is unsuitable for the analyses of the current meta-analysis.

Appendix 3. Studies included in the mediation analysis of loneliness and SIB as a function of depression

Ayalon and Shiovitz (2011); Bennardi (2019); Bonner and Rich (1988); Fulginiti et al. (2018); Gallagher et al. (2014); Groholt et al. (2006); Hom et al. (2019); Joiner and Rudd (1996); Lasgaard et al. (2011); McGraw et al. (2008); Nickel et al. (2006); Pietrzak et al. (2017); Salzinger et al. (2007); Schinka et al. (2013); Stolz et al. (2016); Wistrom (2009). 